\title{
RESPONSABILIDAD OBJETIVA EN EL ORDENAMIENTO JURÍDICO CHILENO*
}

\author{
REGINA INGRID DÍAZ TOLOSA**
}

RESUMEN: En Chile, la responsabilidad civil está inspirada en un fundamento subjetivo; el deber de reparar un daño reside en la conducta dolosa o culposa del autor del mismo. Este sistema es cuestionado por la dificultad que enfrenta la víctima en un juicio al tener que probar la culpa del autor del daño, pues es el demandante a quien corresponde la carga de la prueba. Así pues, en Derecho Comparado, la atención que el sistema tradicional pone en el autor del daño, comienza a trasladarse hacia el perjudicado; se atiende al daño producido, bastando que el daño se produzca para que el autor del becho dañino esté obligado a indemnizar. Sin embargo, en los sistemas latino-continentales, existe un cierto consenso en que las pretensiones de extinguir la responsabilidad fundada en la culpa ban fracasado, y que el factor subjetivo continúa siendo el eje principal del sistema de responsabilidad civil. Existen regimenes sectoriales de responsabilidad objetiva plasmados en legislación complementaria, pero no abrogan el régimen común de los Códigos. No se trata de reemplazar el sistema de la responsabilidad subjetiva, sino de enriquecerlo con nuevos criterios de atribución que dan fundamento justo a la obligación de reparar un daño.

PALABRAS ClAVE: Responsabilidad objetiva - Fundamento responsabilidad civil - Teoría del riesgo - Responsabilidad por culpa - Derecho de daños.

\section{OBJective liability in The Chilean LEGAL CODE}

ABSTRACT: In Chile, the civil responsibility is inspired in a subjective basis; the duty to repair damage, resides in the fraudulent or culpable conduct of the author of the damage. This system is questioned because the difficulty that the victim faces in a trial on having to prove the culpable conduct of the author

\footnotetext{
* Monografía presentada para aprobar el curso Teoria de la Responsabilidad Civili sus dilemas del presente, dictado por la Dra. Carmen Domínguez Hidalgo, dentro del Programa de Doctorado en Derecho impartido por la Pontificia Universidad Católica de Chile, en el primer semestre académico del año 2006.

** Abogada. Doctoranda en Derecho Pontificia Universidad Católica de Chile. Correo electrónico: ingdiaz@terra.cl

Fecha de recepción: 24 de enero de 2007.

Fecha de aprobación: 4 de junio de 2007.
} 
of the damage. This way, in Comparative Law, the attention that the traditional system puts in the author of the damage, begins to move towards the harmed one; one attends only to the damage. Nevertbeless, in the Latin-continental systems, there exists a certain consensus in which the pretensions to extinguish the responsibility been founded on the culpable conduct have failed, and that the subjective factor continues being principal. There are sectorial rates of objective responsibility forming complementary legislation, because they do not abrogate the common regime of the Codes. It is not a question of replacing the system of the subjective responsibility, but to enriching it with new criteria of attribution that give just base to the obligation to repair damage.

KEY WORDS: Objective liability - Civil liability bases - The risk theory - Culpable conduct - Torts.

SUMARIO: Introducción. I. Orígenes de la Teoría de la Responsabilidad Objetiva. II. Responsabilidad objetiva en el ordenamiento juridico chileno. 1. Código Civil: Responsabilidad por el becho de las cosas. 1.1 Daño causado por un animal fiero que no reporta utilidad. 1.2 Daño causado por una cosa que se cae de la parte superior de un edificio. 2. Legislación complementaria. 2.1 Características comunes. a. Sectorizada. b. Moderada con formas de limitación de la responsabilidad. b.1 Tarificación de la indemnización reclamable. b.2 Constitución de seguros obligatorios. b.3 Constitución de fondos de limitación de responsabilidad. b.4 Causas especiales de exoneración de responsabilidad. c. La responsabilidad subjetiva opera como sistema subsidiario. 2.2 Sectores de daños. a. En la empresa, como actividad productiva organizada. a.1 Accidentes laborales. a.2 Daños al medio ambiente. a.3 Daños debido a productos defectuosos. a.4 Responsabilidad de las empresas y servicios públicos. b. En actividades que se relacionan con cosas naturalmente peligrosas. b. 1 Daños causados por vehículos motorizados. 6.2 Daños causados por aeronaves. 6.3 Daños causados por obras de construcción. Conclusiones: Estado actual del fundamento de la responsabilidad civil en Cbile y tendencias en el Derecho Comparado.

\section{INTRODUCCIÓN}

En Chile, la responsabilidad civil está inspirada en los principios clásicos -consagrados en el Código Civil decimonónico- y por ende, el fundamento del deber de reparar un daño, reside en la conducta subjetiva - dolosa o culposa- del autor del mismo y, en ese sentido, la obligación de indemnizar sería una especie de recriminación hacia él por su comportamiento, cumpliendo una función sancionatoria, más que resarcitoria ${ }^{1}$.

Cfr. Abeliuk Manasevich, René: I Las Obligaciones (Santiago, Editorial Jurídica de Chile, 1993, 3“ edición) p. 170; Acosta Ramirez, Vicente: "La responsabilidad objetiva" 
Este sistema ha sido básicamente cuestionado por la dificultad que debe enfrentar la víctima en un juicio al tener que probar la culpa del autor del daño ${ }^{2}$, pues es el demandante a quien corresponde la carga de la prueba. En efecto, en la responsabilidad subjetiva para que el daño producido por un hecho dé lugar a indemnización, es necesario probar que el autor del hecho actuó con dolo o culpa, es decir, es necesario probar que el autor del hecho tuvo la intención de causar el daño si se alega dolo; si se alega culpa, probar que no empleó la diligencia necesaria para evitar el daño causado ${ }^{3}$. Y, al establecer el artículo 1.698 que "incumbe probar las obligaciones o su extinción, al que alega aquellas o esta", el que sostiene que es acreedor a la indemnización por el daño que ha sufrido por un delito o cuasidelito, debe probar su existencia, probar los elementos que los constituyen, entre ellos, el dolo o la culpa ${ }^{4}$.

La responsabilidad civil ha experimentado en las últimas décadas un mayor desarrollo en el Derecho Comparado, esta preocupación nace de la ostensible multiplicación de las situaciones riesgosas a que se ven expuestas las personas en el presente, y la necesidad de proteger a estas y, en especial, a la víctima que sufre un daño ${ }^{5}$. La atención que el sistema

en Cuadernos Juridicos n ${ }^{\circ} 6$ (Viña del Mar, Facultad de Derecho de la Universidad Adolfo Ibáñez, 1996) p. 4 y 5; ALESSANDRI RODRÍGUEZ, Arturo: De la responsabilidad extracontractual en el Derecho Civil chileno (Santiago, Imprenta Universitaria, 1943) p. 92 y 123; Celis Rodríguez, Rubén: Curso especializado de responsabilidad extracontractual (Santiago, Colección Temas Jurídicos y Sociales $\mathrm{n}^{\circ}$ 2, Facultad de Ciencias Jurídicas y Sociales Universidad Central de Chile, 2001, $1^{\text {a }}$ edición), p. 50; Ducci Claro, Carlos: Responsabilidad civil (Santiago, Editorial Jurídica de Chile, 1970) p. 37; Domínguez ÁGuILA, Ramón: "Aspectos contemporáneos de là responsabilidad civil" en Revista de Derecho Universidad de Concepción n ${ }^{\circ}$ 185, año 1989, p. 111-113; FueYo LANERI, Fernando: Cumplimiento e incumplimiento de las obligaciones. Edición actualizada por el profesor Gonzalo Figueroa Yáñez (Santiago, Editorial Jurídica de Chile, 2004, 3ª edición) p. 393; LóPEZ SANTA MARIA, Jorge: "La responsabilidad civil por productos" en AA.VV.: Derecho de daños (Santiago, LexisNexis, 2002), p. 149; Molinari VALDÉs, Aldo: De la responsabili-

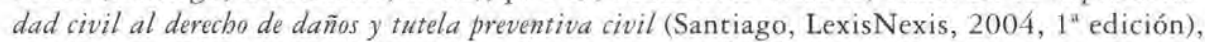
p. 19 y 71; VÁZqueZ FerReYra, Roberto: Responsabilidad por daños (elementos) (Buenos Aires, Ediciones Desalma, 1993), pp. 38-41, y 196. El español Difz-PICAZO, Luis en su artículo "Responsabilidad civil hoy" en Anuario de Derecbo Civil, tomo 32, fascículo IV, octubre-diciembre 1979, pp. 728 y 729 , trata acerca de los presupuestos ideológicos y la estructuración del sistema de responsabilidad civil en el Derecho Civil codificado, explicando que los códigos decimonónicos son de carácter individualista, dadas las relaciones económicas y sociales de la época y la influencia del Derecho Canónico, el sistema de responsabilidad civil estaba destinada a moralizar la conducta del autor del daño, constituyendo la obligación de resarcir una sanción.

Tomasello Hart, Leslie: Estudios de Derecho Privado (Valparaíso, EDEVAL, 1994) p. 65, señala que en un juicio el tema de la prueba es fundamental, a tal punto que sin probar la culpa no hay responsabilidad. Así pues, ABELıuk (n. 1), p. 170, señala que "se comenzó a advertir que raramente la víctima obtenía reparación, y sin mucho estudio fue fácil concluir que la razón principal estribaba en sus dificultades para probar la culpa".

Cfr. Celis (n. 1), p. 51; DuCCI (n. 1), p. 29.

Ducci (n. 1), p. 84

Cfr. v.g., Abeliuk (n. 1), p. 171 y 174; López (n. 1), p. 149; MOlinari (n. 1), pp. 7 12 , y 20 . 
tradicional ha puesto en el autor del daño, comienza a trasladarse hacia el perjudicado, lo que motiva incluso una denominación diferente de la materia, que soslaye el problema de la sanción y se radique en el de la reparación. Así pues, se habla de un "derecho de daños" en vez de "responsabilidad civil", pasando del principio de "no hay responsabilidad sin culpa" al de "todo daño debe ser reparado", fórmula que pretende resaltar el acento claramente resarcitorio que en el presente caracteriza a la responsabilidad. Existe un traslado de la responsabilidad hacia la reparabilidad, donde el daño es el presupuesto en torno del cual se centra el fenómeno resarcitorio. Así se habla de principio pro damnato, para referirse a la idea que todos los perjuicios y riesgos que la vida social ocasionan, deben ser resarcidos ${ }^{6}$.

En la responsabilidad objetiva se prescinde en absoluto de la conducta del sujeto, no se mira su culpabilidad, se atiende única y exclusivamente al daño producido, basta que este daño se produzca para que el autor del hecho dañino esté obligado a indemnizar ${ }^{7}$. Así, el problema de la responsabilidad se traduce en un asunto de causalidad y no de imputabilidad; basta encontrar la relación de causalidad entre el hecho y el daño producido, no siendo necesaria la relación de reprochabilidad entre el autor del hecho y el hecho mismo ${ }^{8}$. Estando la clave en determinar cuándo un daño merece ser indemnizado?

Sin embargo, en los sistemas latino-continentales, existe un cierto consenso en que las pretensiones de extinguir la responsabilidad fundada en la culpa han fracasado, y que el factor subjetivo continúa siendo el eje principal del sistema de responsabilidad civil. Existen regímenes sectoriales de responsabilidad objetiva plasmados en legislación complementaria, pero no abrogan el régimen común de los Códigos -fundado en la idea de la culpa-, sino que establecen normas especiales de carácter su-

6 Cfr. ACosta (n. 1), p. 31; Fueyo (n. 1), p. 396; DíEz-PICAzo (n. 1), p. 727, 732 y 734; Molinari (n. 1), p. 14 y 20; VÁZQUez (n.1), p. 39, 41-42 y 45 y 46; Corral TALCiAni, Hernán: Lecciones de responsabilidad civil extracontractual (Santiago, Editorial Jurídica de Chile, 2003, $1^{\text {a }}$ edición) pp. 90 y 91.

7 Cfr. Abeliuk (n. 1), p. 171; DuCCI (n. 1), p. 29; Rodríguez Grez, Pablo: La obligación como deber de conducta típica (La teoria de la imprevisión en Chile) (Santiago, Facultad de Derecho de la Universidad de Chile, 1992, 1ª edición) pp. 93 y 94. Por lo demás, así lo ha indicado la jurisprudencia de nuestros tribunales: En la responsabilidad objetiva, "se prescinde del elemento culpabilidad, puesto que aquí basta que con una actividad o hecho se cause un daño a la persona o propiedad de otro, para que nazca el deber de responder de él". Palma González con Municipalidad de Concepción (2002): Corte Suprema, recurso de casación, 7 de mayo de 2002, en LexisNexis 24432, Considerando $9^{\circ}$. En el mismo sentido, Quezada Salazar y otros con Fisco de Chile (2000): Corte de Apelaciones de Santiago, 4 de marzo de 2000, en LexisNexis 33059, considerando $1^{\circ}$. 
pletorio o complementario ${ }^{10}$. No se trata de reemplazar el sistema de la responsabilidad subjetiva, sino de enriquecerlo con nuevos criterios de atribución que dan fundamento justo a la obligación de reparar un daño ${ }^{11}$.

A continuación se profundizará la temática anunciada, explicando someramente los orígenes de la teoría de la responsabilidad objetiva, cómo nace y se desarrolla, quiénes son sus principales creadores y detractores, para luego centrarnos en la situación chilena. La legislación chilena en base a qué fundamento de la responsabilidad se desarrolla y cómo se ha ido objetivando el sistema, desde luego, se analizará para ello nuestro Código Civil y la legislación complementaria que plasma la teoría objetiva, asimismo, se revisarán casos jurisprudenciales atingentes, sin dejar de mencionar la opinión de los doctrinarios chilenos en torno a la cuestión, todo ello en pertinente contraste con el Derecho Comparado, fundamentalmente, considerando países pertenecientes a la familia germanoromana, por haber influido fuertemente en los procesos de codificación chilenos; principalmente, Francia y España.

\section{ORÍGENES DE LA TEORÍA DE LA RESPONSABILIDAD OBJETIVA}

Desde y durante varios siglos primó sin admitir discusiones el fundamento subjetivo de la culpa. No se puede aseverar que existe este fundamento de la responsabilidad desde la Ley Aquilia (s. V a. C.), pues al respecto existen variadas interpretaciones, para algunos funcionaba como responsabilidad objetiva, y habrían sido los maestros de la escuela oriental, inspirados en la obra de ULPIANO, los que introdujeron la idea de culpa. Otros, por su parte, sostienen que la idea de culpa se introdujo en las interpretaciones de la jurisprudencia clásica, o bien, a raíz de la jurisprudencia romana interpretada por el pretor ${ }^{12}$.

Quienes sistematizan este régimen clásico de responsabilidad son Hugo Grocio, Jean Domat y Robert Joseph PothiER; y la regla general de que todo daño inferido a otro debe ser reparado si se debe al hecho o

10 Cfr. Domínguez (n. 1), p. 116; Corral (n. 6), p. 102; Yuseff Quirós, Gonzalo: Fundamentos de la responsabilidad civil y la responsabilidad objetiva (Santiago. Editorial La Ley, 2000, 1a edición) p. 193.

11 VÁZQUEZ (n.1), pp. 42 y 43.

12 Cfr. Acosta (n. 1), p. 3; Domínguez (n. 1), p. 111; Corral (n. 6), p. 80; GuZmán BRITO, Alejandro: II Derecho privado romano (Santiago, Editorial Jurídica de Chile, 1996) p. 258; MAzeud H. y otros: Tratado teórico y práctico de la responsabilidad civil delictual y contractual (Buenos Aires, Ediciones Jurídicas Europa - América, 1961, $5^{\text {a }}$ edición) pp. 42 y 43; D'ors, Álvaro: Derecho privado romano (Pamplona, Eunsa, 1989, $7^{\text {A }}$ edición) p. 427 ; NAVARrete Barrueto, Jaime: "El origen de la responsabilidad civil objetiva en el derecho aéreo" en Revista Chilena de Derecho vol. 5 ns 1-6, febrero-diciembre 1978, p. 160. 
culpa del autor, queda plasmada en el Código francés de Napoleón de $1804^{13}$. De ahí, que la construcción del sistema de responsabilidad sobre el principio de la culpa sea común a todo el derecho occidental, pues, por cierto, aparece en todas las legislaciones derivadas del mencionado Código ${ }^{14}$, considerándose una solución justa: debe sancionarse a quien causa un daño por un acto voluntario y culpable, de otra forma, sería injusto y antijurídico responsabilizar al inocente ${ }^{15}$.

Recién a partir de la segunda mitad del siglo XIX y primeras décadas del siglo XX, se comienza a poner en cuestión el principio de "no hay responsabilidad sin culpa"; la paulatina complejidad que adquirieron las relaciones sociales en todo ámbito -económico, cultural, político-, y la búsqueda de la protección del más débil ${ }^{16}$, hicieron que los doctrinarios empezaran a replantearse el problema del fundamento de la responsabilidad civil, originándose una corriente de pensamiento ${ }^{17}$ que encuentra el fundamento de la responsabilidad, no en la culpa sino en el riesgo creado por la actividad que produce el daño ${ }^{18}$.

Así, por ejemplo, la situación de los obreros en las fábricas, recién iniciada la revolución industrial, y su situación frente a los accidentes del trabajo, originó que Saleilles publicara, en 1897, un trabajo titulado Les accidents au travail et la responsabilité civile. Para Saleilles, era inconcebible

13 Cfr. ACosta (n. 1), p. 4.

14 De esta forma, el profesor Domínguez (n. 1), p. 112, señala que es importante recordar que este principio general vale solo para los derechos romanistas y no para el Common Law.

15 Para más detalle, Vid. Domínguez (n. 1), p. 111-113; Corral. (n. 6), pp. 81-86.

16. Cfr. Abeliuk (n. 1), p. 170 y 171; ACOSTA (n. 1), p. 1; Diez-Picazo (n. 1), p. 732; Dominguez (n. 1), p. 114; Fueyo (n. 1), pp. 393 y 394; MOLINARI (n. 1), pp. 7-12, y 20; VÁzQuez (n. 1), p. 38-41; Corral (n. 6), p. 87; Rodríguez (n. 7), p. 94; NAvaRRETE (n. 12), pp. 162 y 163; RODRÍGUEZ GREZ, Pablo: Responsabilidad extracontractual (Santiago, Editorial Jurídica de Chile, 2002, 1ª edición) p. 61 y 198; SÜSS TH.: "La evolución de la responsabilidad por riesgo en el moderno derecho alemán" en Revista de Derecho Privado volumen XXVII n 311 año 1943, pp. 54-56.

17 Cfr. Alessandri (n. 1), p. 113 y VÁzQUez (n. 1), p. 39: Alemania: Mataja (1888), Italia; ORLANDO (1894) y Francia: SALEILLES y JOSSERAND (1897).

18. Cfr. Abeliuk (n, 1), p, 171; Celis (n. 1), p. 50; Fueyo (n. 1) p. 394; López (n. 1), p. 151; MOLINARI (n. 1), p. 71 y 72; ROdRÍGUEZ (n. 7), pp. 93 y 94; RodríGUez (n. 16) p. 60, 111 y 193; Süss (n. 16), p. 55.

Cabe hacer notar que al surgir la teoría de la responsabilidad objetiva, su fundamento -la justificación de poner el daño a cargo de determinada persona-se veía en el riesgo creado por la actividad peligrosa desarrollada, sin embargo, se debe precisar que actualmente se conocen otros fundamentos, como por ejemplo, la equidad, la garantía, el seguro, la solidaridad, entre otros. Estos, en general, son denominados factores objetivos de atribución y tienen en común el prescindir del análisis valorativo de la conducta del agente que causa un daño. VÁzQuez (n. 1), p. 197, señala que el fundamento de la reparación en los factores objetivos de atribución "está en una causa externa, distinta del juicio valorativo que merezca la conducta dañosa". Y añade que "constituyen un catálogo abierto sujeto a expansión", el cual (p. 207) "se ampliará por la dinámica de la doctrina, legislación y jurisprudencia"; cfr. MOLINARI (n. 1), p. 73. 
obligar al obrero a probar la culpa del empleador de los accidentes del trabajo toda vez que, en la mayoría de los casos, tal culpa no existía, lo que dejaba latente una poderosa injusticia ${ }^{19}$.

Así pues, esta teoría ha sido muy recurrida frente a los daños producidos por organizaciones en las que es muy complejo individualizar al culpable, o en que no existe propiamente culpa en estricto rigor, ya que el daño es estadísticamente necesario a una determinada actividad productiva $^{20}$.

Esta teoría seduce por su simplicidad. Ofrece la ventaja de evitar un difícil análisis sobre la conducta humana y toda indagación acerca de las intenciones del agente ${ }^{21}$. En sus inicios tuvo grandes seguidores en todos los países de Europa, e influyó en la jurisprudencia ${ }^{22}$. Sin embargo, si bien muchos autores se entusiasmaron con el proceso objetivador y comenzaron a hablar de la socialización del riesgo, otros, comenzaron a delimitar qué riesgos podían justificar la atribución de responsabilidad sin culpa. De lo contrario, se aducía, nadie podía quedar libre de ser responsable, pues la creación de un cierto nivel de riesgo es inseparable de toda actividad humana ${ }^{23}$.

Dentro de los grandes detractores de la teoría de la responsabilidad sin culpa, se puede mencionar al francés Marcel PLANIOL, quien la critica rotundamente por estimarla inadecuada ${ }^{24}$; suprime el elemento moral que es esencial en toda responsabilidad; paraliza la iniciativa privada e inhibe la actuación particular; y, tiende a convertirse en una responsabilidad por seguro, lo que trae mayor descuido y mayores accidentes ${ }^{25}$.

Cfr. ACosta (n. 1), p. 6; Celis (n. 1), p. 50; Domínguez (n. 1), p. 115; López (n. 1), p. 151; VAZQUeZ (n. 1), p. 39; YUSEFF (n. 10), p. 163; NAVARRETE (n. 12), p. 163. CORRAL (n. 6), p. 89.

21 PLANIOL, Marcel: Traité pratique de droit civil français (1945). Edición traducida al español, VI Tratado práctico de Derecho Civil francés. Las Obligaciones: primera parte (Mario Díaz Cruz, Habana, Editorial Cultural S.A., 1946) p. 669.

22 "En Francia, la jurisprudencia utilizó el artículo 1384 del Código Civil (responsabilidad por el hecho de las cosas inanimadas) para cubrir supuestos de daños producidos por tranvías y ferrocarriles. En otros países, como Iralia y España, la aceptación de la doctrina de la responsabilidad objetiva fue acogida por razones de equidad por la jurisprudencia". CORRAL (n. 6), p. 89

23 Ibídem; ABELIUK (n. 1), p. 172, señala que cuñado se ha llevado a extremos las doctrina objetiva de la responsabilidad, esta ha recibido severas críticas, pues si bien "ampara a una víctima frente al daño que se le ha ocasionado facilitándole el cobro de la indemnización, por otro lado fomenta la existencia de nuevas víctimas, porque si de todos modos habrá que reparar, puede introducirse en la conciencia general la idea de que ante el Derecho da igual actuar con diligencia o sin ella, ya que siempre se responderá del daño que pueda llegarse a ocasionar".

24 Vid. apartado $n^{\circ} 480$ "Crítica de la Teoría del Riesgo" en Planiol (n, 15), pp. 670-672.

25 Cfr. DUCCI (n. 1), p. 33; CORRAL (n. 6), p. 91. De acuerdo a ALESSANDRI (n. 1) pp. 116119, autores eminentes como Planiol, RIPERT, MAZEAUd, COLIN y CAPITANT, entre otros, combaten abiertamente la teoría, mencionando como argumentos: 1 . Suprime el elemento moral de la responsabilidad civil, 2. Al reducir el tema a una cuestión de 
Así pues, se ha planteado que en vez de tratar de sustituir la responsabilidad subjetiva por una objetiva, se ha de complementarlas, enriqueciéndolas una con la otra; ambas teorías son absolutamente compatibles ${ }^{26}$.

\section{RESPONSABILIDAD OBJETIVA EN EL ORDENAMIENTO JURÍDICO CHILENO}

El régimen chileno, al igual que el francés, utiliza la técnica de disponer una regla general y abstracta prohibiendo inferir daño a otro y reservando a la labor judicial el precisar en concreto qué hechos pueden tener cabida dentro de ese principio general ${ }^{27}$.

El Código Civil francés enuncia como marco general de toda la regulación de la responsabilidad civil una norma que actúa como cláusula general, a la que deberán reconducirse los supuestos específicos: "todo hecho del hombre que haya ocasionado daño a otro obliga al culpable a repararlo" (artículo 1.382). Nada se dice sobre qué daño y cómo debe ser causado para que imponga responsabilidad. Se trata solo de la recepción legal del principio general de que nadie debe causar daño a otro ${ }^{28}$, fundando la reparación del daño en la culpabilidad del causante de él.

Así pues, no hay duda que el régimen chileno recoge el principio general antes referido en el Código Civil, por ejemplo, el artículo 2.314 dispone que aquel "que ha cometido un delito o cuasidelito que ha inferido daño a otro, es obligado a la indemnización", y por su parte, el artículo 2.329 señala que "todo daño que pueda imputarse a malicia o negligencia de otra persona, debe ser reparado por esta”. Asimismo, se desprende de distintos artículos ${ }^{29}$ del mencionado Código, que el funda-

causalidad, no implica necesariamente una simplificación del problema, pues si un daño es generado por varias causas, igualmente habrá dificultad para establecer la determinante, 3. Paraliza la iniciativa y espíritu de la empresa, 4. Al existir seguros los hombres tienden a ser más irresponsables, 5. No es justa ni equitativa; Cfr. RODríguez Grez, Pablo: Responsabilidad extracontractual (Santiago, Editorial Jurídica de Chile, 2002, $1^{\text {* }}$ edición) pp. 64 y 65, y Celis (n, 1), p. 52.

Vid. y.g. Alessandri (n. 1), p. 120; RODRÍGUeZ GREZ, Pablo: Responsabilidad extracontractual (Santiago, Editorial Jurídica de Chile, 2002, 1ª edición) pp. 65, 66, 110 y 111 ; Celis (n. 1), p. 53 ,

CORRAL (n. 6), p. 94.

Ibídem.

29 V.g., Artículo 44 que distingue tres clases de culpa; artículo 1.547 que trata de las distintas clases de culpa en relación a diversos tipos de contrato; 1.558 señala cuáles perjuicios deben ser indemnizados dependiendo de la concurrencia de dolo; artículo 2.319, que declara a los incapaces absolutos irresponsables en materia delictual y cuasidelictual; artículo 2.321 que se refiere a la culpa de los padres en la educación de los hijos; artículo 2.323, tratándose de los daños causados por la ruina de un edificio, cuando ha habido culpa; artículo 2.326, que trata de la responsabilidad del dueño de un animal, $y$ del que se sirve de un animal ajeno. 
mento de la reparación del daño es la culpa con la que ha obrado el agente causante del mismo.

La técnica empleada no quita que el legislador proceda a describir anticipadamente conductas que deben ser consideradas ilícitas y generadoras de responsabilidad vinculando así el poder de apreciación del juez ${ }^{30}$. De hecho, hoy pareciera no aceptable que los cambios de la atribución de responsabilidad sean realizados de modo intuitivo por el juez ${ }^{31}$, más bien se considera razonable que los supuestos de responsabilidad objetiva sean definidos y regulados por la ley ${ }^{32}$.

Esto se condice con que la responsabilidad sin culpa ha dejado de ser, en la actualidad, un modelo de responsabilidad que aspire a sustituir al criterio de la negligencia. Y de esta forma, la recepción legal del modelo ha sido fragmentaria y sectorizada, en ciertos ámbitos de actividades especialmente riesgosas se han dictado normas sobre responsabilidad por culpa presunta o por riesgo creado; por ejemplo, por daños empresariales al medio ambiente, productos defectuosos, accidentes de circulación, navegación marítima o aérea, daños por actos terroristas, y otros de similar naturaleza ${ }^{33}$.

Al respecto, nuestra jurisprudencia ha fallado ${ }^{34}$ que la responsabilidad sin culpa "no existe sino por excepción y en los casos expresa e inequívocamente señalados por la ley. La regla general consiste en que la responsabilidad emana del dolo o de la culpa, en cualquiera de sus gamas"35. Y de esta forma, "la excepcionalidad del mecanismo impide su

30 CORRAL (n. 6), pp. 95 y 96.

31 Antes que existiera legislación especial respecto de ciertas materias, v.g., accidentes del trabajo y accidentes de circulación de vehículos, el juez ya había comprendido la existencia de una responsabilidad más estricta, se consideraba en forma práctica cada caso en particular, haciendo justicia sin buscar teorías generales de responsabilidad, en DUCCI (n. 1), pP. 105-110, se dan más detalles al respecto, reproduciendo sentencias de la primera mitad del siglo XX.

32 Cfr. Corral (n. 6), p. 101; López (n. 1), p. 150, nos da indicios de lo que ocurre al respecto en otras legislaciones, indicando que en Alemania la responsabilidad objetiva requiere texto legal expreso e inequívoco, pero que en general, el derecho de daños contemporáneo se caracteriza por un protagonismo de los jueces, es decir, las hipótesis de responsabilidad sin culpa se imponen por la vía interpretativa, sin texto legal categórico.

33 CORRAL (n. 6), p. 221.

34 Vid. v.g., Considerando $7^{\circ}$ y $8^{\circ}$, Corte de Apelaciones de Santiago, 21 de noviembre de 2003 , en Gaceta Jurídica $n^{\circ} 281$, p. 122: “( ...) lo que se conoce bajo la denominación de responsabilidad objetiva, siempre excepcional y que encuentra su fundamento necesario en una norma legal que explícitamente la consulte. Entre los casos constitutivos de otras tantas hipótesis de responsabilidad objetiva, podemos citar, verbigracia, el artículo 155 del Código Aeronáurico; el artículo 21 del Código de Minería; el artículo 49 de la ley $\mathrm{N}^{\circ}$ 18.302, de 1984; el artículo $8^{\circ}$ del D.L. $\mathrm{N}^{\circ} 3.557$, de 1981; el artículo 17 de la Ley Orgánica Constitucional de los Estados de Excepción Constitucional, $\mathrm{N}^{\circ} 18.415$, de 1985; el artículo 52 de la ley $\mathrm{N}^{\circ}$ 19.300, de 1994; el artículo $1^{\circ}$ de la ley $\mathrm{N}^{\circ} 18,617$, de 1987; el artículo 144 del D.L. N ${ }^{\circ} 222$, sobre ley de Navegación, etc."

35 Corte de Apelaciones de Santiago, recurso de apelación, 22 de enero de 1990, en LexisNexis 19813. 
configuración por vía de integración normativa o por pura deducción hermenéutica" 36 . En otras palabras, en nuestro sistema no puede haber objetivación de la responsabilidad por analogía ${ }^{37}$ o interpretación judicial, siendo necesaria la intervención del legislador. En los casos dudosos, habrá de seguirse el criterio de la responsabilidad subjetiva ${ }^{38}$.

\section{Código Civil: Responsabilidad por el hecho de las cosas}

Al tratar de sistematizar el análisis del Código, en términos generales, se puede decir que en cuanto a la responsabilidad por el hecho personal, sigue el principio subjetivo basado en la culpa; tratándose de la responsabilidad por el hecho de terceros, la responsabilidad es subjetiva pero presumida ${ }^{39} ;$ y, por el hecho de las cosas, se sigue la regla de responsabilidad objetiva, en la mayor parte de los casos.

Arauco Generación Sociedad Anónima con Superintendencia de Electricidad y Combustibles SEC (2005): Corte Suprema, 8 de noviembre de 2005, en LexisNexis 33234.

37. En ese sentido, v.g. Stuart Powell con Empresa Eléctrica de Aysén Sociedad Anónima (2004): Corte Suprema, recurso de casación, 2 de noviembre de 2004, en LexisNexis 31340.

39. La regla general en materia de responsabilidad es que se responde de las consecuencias de los propios actos, sin embargo, en materia extracontractual, el Código obliga a una persona a responder de los hechos de un tercero, cundo este está sometido al cuidado, protección o vigilancia de aquel a quien la ley hace responsable. La materia se trata en el artículo 2.320, en el cual se da un principio general y se señalan casos ejemplares en los cuales esta responsabilidad procede: padres respecto hijos menores que habiten en la casa, guardador respecto del pupilo, jefes de establecimientos educacionales respecto a sus alumnos mientras permanezcan en el lugar, empleadores respecto de los hechos de sus dependientes.

Es característica fundamental de esta responsabilidad por el hecho del tercero, la circunstancia de que se trata de una responsabilidad por culpa presumida. Esto es, tratándose de la responsabilidad por el hecho del tercero, en los casos en que la ley la establece, la víctima no necesita probar la culpa del autor del daño, ya que esta culpa es presumida correspondiendo al que debe responder, si quiere excusar su responsabilidad, demostrar su ausencia de culpa. De esta forma el legislador ha incluido un paliativo o morigeración al principio general de la culpa.

En la presente investigación no se consideran estos casos de culpa presunta en el estudio, pues si bien tienden a la objetivación -como se ha explicado más arriba-, no contienen un fundamento objetivo de la responsabilidad, entendido como aquel en que solo es necesaria la causalidad entre hecho dañoso y daño producido, no siendo necesario por parte de la víctima probar la culpa del actor del hecho, ni tampoco siendo posible para este exonerarse de la responsabilidad por haber empleado la debida diligencia. En el mismo sentido, RODRÍGUEZ (n, 16), p. 205 quien indica que le parece absolutamente errado, confundir -como lo hacen algunos autores- los casos de responsabilidad objetiva con las presunciones de culpa; lo que no se entiende es que el artículo 2328 del Código Civil (cosas que se caen o arrojan de la parte de un edificio), lo trate en la obra en comento tanto en el acápite destinado a la responsabilidad objetiva (p. 203) como en el acápite de la presunción de culpa por el hecho de las cosas (p. 248).

Así pues, esta investigación se basa en el estudio de la responsabilidad objetiva considerando el término en forma restringida, como indica YUSEFF (n. 10), p. 157, como "aquel sistema de responsabilidad que fundamenca la obligación indemnizatoria en la mera cau- 
Así pues, en este último caso, la responsabilidad se origina sin que sea necesario ni acreditar la culpa ni permitido exonerarse por haber empleado la diligencia debida, pues como se ha dicho más arriba, solo importa el nexo causal entre hecho que origina el daño y el daño mismo. Así sucede tratándose del daño causado por un animal fiero del que no se reporta utilidad ${ }^{40}$; y en el caso de los daños causados por una cosa que se cae o arroja de la parte superior de un edificio ${ }^{41}$.

Cabe precisar que en esta materia, nuestro Código a diferencia del francés $^{42}$ no contiene una norma que establezca en general la responsabilidad por el hecho de las cosas que se tienen bajo guarda.

\subsection{Daño causado por un animal fiero del que no se reporta utilidad}

En cuanto a la responsabilidad derivada de los daños causados por animales, la regla general que sigue nuestro Código, es que el dueño del animal, así como el que se sirve de él, es responsable de los daños causados por el animal mismo, aun después de que se haya soltado o extraviado, salvo que no pueda imputarse culpa ${ }^{43}$.

Ahora, si el animal es fiero y no reporta utilidad para la guarda o servicio de un predio, la responsabilidad afecta al que lo tenga. $Y$ es un caso de responsabilidad objetiva, pues no está permitido acreditar ausencia de culpa para evitar la indemnización ${ }^{44}$.

Se trata claramente de un supuesto de responsabilidad objetiva, donde el fundamento de tal responsabilidad es la creación del riesgo que crea quien, sin necesidad mantiene un animal peligroso. Así pues, no se aplicaría la norma si el animal presta algún servicio o utilidad, aunque no sea en beneficio de un predio, por ejemplo, tratándose de animales en

salidad material, es decir, que requiere como elementos de la obligación de reparar la sola relación de causalidad entre el perjuicio y el hecho del hombre, esto es, solo elementos objetivos, sin considerar los elementos subjetivos",

Para detalle sobre la materia de las presunciones de culpabilidad, Vid. Abeliuk (n. 1), p. 174, 175, 181 y 182; Celis (n. 1), p. 51; Corral (n. 6), pp. 240-249; Domínguez (n. 1), pp. 117 y 118; DuCCI (n. 1), pp. 34-36, 89-95; YUSEFF (n. 10) pp. 144-150; NAVARRETE (n. 12), pp. 161 y 162; ROdRÍGUEZ (n. 16), p. 62, 209-254; SÚss (n. 16) pp. 65-69.

40 Artículo 2.327 del Código Civil.

41 Artículo 2.328 del Código Civil.

42 Artículo 1.384 inciso $1^{\circ}$ : "La persona será responsable no solamente del daño que cause por su propia actuación, sino también por el que causara por la actuación de personas de las que deba responder, o de cosas que permanezcan bajo su guarda."

43 Artículo 2.326 del Código Civil: "El dueño de un animal es responsable de los daños causados por el mismo animal, aun después que se haya soltado o extraviado; salvo que la soltura, extravío o daño no pueda imputarse a culpa del dueño o del dependiente encargado de la guarda o servicio del animal. / (inciso $2^{\circ}$ :) Lo que se dice del dueño se aplica a toda persona que se sirva de un animal ajeno (...)".

i4 Artículo 2.327 del Código Civil: "El daño causado por un animal fiero, de que no se reporta utilidad para la guarda o servicio de un predio, será siempre imputable al que lo tenga, y si alegare que no le fue posible evitar el daño, no será oído". 
un zoológico o circo que satisfacen necesidades de entretención y diversión 45 .

El Código francés ${ }^{46}$ es más objetivo en esta materia, pues no hace alusión alguna a la culpa: "El propietario de un animal, o quien se sirva de este, mientras estuviera usándolo, será responsable del daño que el animal haya causado, bien que el animal estuviera bajo su guarda, o bien que se hubiera extraviado o escapado".

Cabe hacer notar que en la doctrina nacional no es unánime la opinión de ser este un caso de responsabilidad objetiva. En efecto, algunos autores sostienen que se trataría de una responsabilidad con presunción de culpa, así por ejemplo ABELIUK indica que "podría pensarse que se trata de un caso de aplicación de la teoría del riesgo, pero en verdad lo que ocurre es que se niega toda posible exención al que tiene un animal fiero, porque su imprudencia y negligencia son tan ostensibles que el legislador las considera indiscutibles" 47 .

Nosotros no estamos de acuerdo con este argumento, pues nos parece que no se trata de una cuestión de negligencia, sino de creación de riesgo; el que mantiene un animal fiero del cual no se obtiene beneficio alguno crea un riesgo innecesario para la integridad de las personas de frente a posibles ataques de la bestia. El tema de la diligencia debida en materia de animales fieros solo tendría aplicación respecto de aquellos que sí reportan una utilidad o servicio, como por ejemplo, en el caso del perro fiero guardián de un predio, o de un tigre amaestrado del circo, o de un oso en exhibición en un zoológico ${ }^{48}$.

\subsection{Daño causado por una cosa que se cae o arroja de la parte supe- rior de un edificio}

De este daño responden todas las personas que habitan la misma parte del edificio y la indemnización se dividirá entre todas aquellas,

45 Cfr. Alessandri (n. 1), p. 408; Corral (n. 6), p. 247.

46 Artículo 1.385.

47 ABeLIUK (n. 1), p. 232.

48. Así, el argentino VÁsQuez, p. 201 indica que "el descarte de la posibilidad de probar la no culpa muestra que el elemento subjetivo no está en juego. En este caso el factor de atribución es objetivo: riesgo creado (...) hay que asumir que en aquellos casos en que la culpa no interesa es porque en realidad se trata de una responsabilidad objetiva". Por otro lado GonZÁlez Guerrico, César: "Responsabilidad por los animales" en López CABANO, Roberto M. (coordinador): Responsabilidad civil abjetiva (Buenos Aires, AbeledoPerrot, 1995), pp 165-169, y 174, al analizar el artículo del Código Civil argentino que es muy similar al nuestro, lo interpreta como un caso de responsabilidad objetiva, y así también dice lo sostienen otros juristas argentinos, mencionando entre ellos a LLAMBÍAS y ALTERINI.

En la doctrina nacional Celis (n. 1), p. 97, también sostiene se trataría de una presunción de culpa de derecho. En cambio Acosta (n. 1), p. 9; RODRíGuez (n. 7), p. 94 y RODRíGUEZ (n. 16), pp. 203 y 204 , lo tratan como un caso de responsabilidad objeriva. 
siendo por tanto, la regla general que todas ellas sean responsables, sin necesidad de probar la culpa por parte de la víctima, ni tampoco les es posible a los responsables exonerarse del pago de la indemnización probando la debida diligencia.

Así pues, el supuesto esencial de esta norma reside en la imposibilidad de probar que el hecho se debe a culpa o dolo de un sujeto determinado, generándose un caso de responsabilidad objetiva, pues existe una obligación de reparar un daño sin atender al elemento subjetivo de la responsabilidad ${ }^{49}$.

Se trata de una responsabilidad colectiva; la ley entiende legitimado al grupo dentro del cual se encuentra un responsable único pero anónimo, siendo la obligación de responder no solidaria, pues la indemnización se divide entre todos los responsables ${ }^{50}$. EI ser una responsabilidad colectiva demuestra que tras la norma existe un fundamento objetivo de la responsabilidad; lo que importa es la reparación del daño causado y no la moralización de la conducta del agente del daño. La responsabilidad no tiene otro fundamento que el interés social y el amparo de quienes sufren el daño, siendo evidente que se privilegia a la víctima, quien de otra manera se habría visto privada de toda reparación posible ${ }^{51}$.

Existe una referencia a la culpa, al permitir que los responsables se exoneren de la indemnización, si prueban que el hecho se debe a la culpa o mala intención de alguien exclusivamente, en cuyo caso solo este será el responsable $e^{52}$.

Esta alusión a la culpa, no implica que el fundamento sea subjetivo "objetivado" con una presunción de responsabilidad; la posibilidad que tiene alguien para eximirse de la indemnización probando que solo uno de ellos es culpable, solo hace que la responsabilidad colectiva se transforme en individual. Sin embargo, la mayor parte de los autores consultados en esta investigación, tratan esta materia dentro de las presunciones de responsabilidad; la víctima no tendría que probar la culpa, pues existe una presunción respecto a todos los que habitan la misma parte del edificio de la cual cayó el objeto ${ }^{53}$. Nosotros lo hemos incluido como un caso de responsabilidad objetiva pues creemos tampoco se les está permi-

\footnotetext{
49 Cfr. Rodríguez (n. 16), p. 203.

50 Cfr. Corral (n. 6), p. 249; Dízz-PiCazo (n. 1), pp. 733 y 734.

51 Cfr. RODRíguez (n. 16), p. 203.

52 Inciso $1^{\circ}$, artículo 2.328 del Código Civil: "El daño causado por una cosa que cae o se arroja de la parte superior de un edificio, es imputable a todas las personas que habitan la misma parte del edificio, y la indemnización se dividirá entre todas ellas; a menos que se pruebe que el hecho se debe a la culpa o mala intención de alguna persona exclusivamente, en cuyo caso será responsable esta sola".

53 V.g. Cfr. Abeliuk (n. 1), p. 234; Alessandri (n. 1), p. 447; Celis (n. 1), p. 96; CorRAL (n. 6), p. 249 .
} 
tido, a quienes la ley atribuye la responsabilidad, exonerarse probando debida diligencia ${ }^{54}$.

\section{Legislación complementaria}

Parece sensato que el Código Civil haya establecido una responsabilidad objetiva en el caso de los animales fieros que no reportan utilidad $y$, de las cosas que caen o se arrojan de la parte superior de un edificio, pues justamente eran los peligros existentes en el siglo XIX. Los supuestos de responsabilidad objetiva estaban pensados para una economía pequeña y doméstica, donde los sistemas de producción eran artesanales y agrícolas, en que los riesgos que generaban nada tienen que ver con el nuevo orden de cosas y con una economía mucho más desarrollada ${ }^{55}$.

Sin embargo, en la actualidad, se han ido diversificando las situaciones de peligro, dada la complejidad y progreso de la forma de vida moderna, exponiendo a los individuos a mayores y variados riesgos. De esta forma el legislador del siglo XX y XXI ha ido plasmando el criterio de respnsabilidad objetiva en ciertas leyes especiales.

\subsection{Características comunes}

\section{a) Sectorizada}

El legislador chileno al igual que los sistemas de responsabilidad civil de los ordenamientos continentales, ha establecido en leyes complementarias al Código Civil, excepcionalmente casos concretos fundados en la responsabilidad objetiva, justificándose la mayor parte de ellos en la teoría del riesgo-provecho, o en la de riesgo creado $^{56}$. Así se han creado microsistemas normativos de responsabilidad para sectores especiales donde se ha estimado que conviene la adopción de otros criterios que favorecen a la víctima, sin afectar en demasía el costo de las actividades productivas $^{57}$.

Así pues, la responsabilidad objetiva parece razonable en ciertos sectores de la legislación en que los daños resultan difícilmente repara-

\footnotetext{
54 En el mismo sentido Rodríguez (n. 16), p. 203, aunque con el reparo hecho en la nota 39: trata el tema tanto como un caso de responsabilidad objetiva (p. 203), así también como un caso de presunción de culpa por el hecho de las cosas (p. 248).

55 Zelaya Etchegaray, Pedro; "La responsabilidad subsidiaria del dueño de obra por los accidentes y daños experimentados por el trabajador del contratista" en BARAONA GONZÁlez, Jorge y ZeLAYA ETCHEGARAY, Pedro (editores): La responsabilidad por accidentes del trabajo (Santiago, Cuadernos de Extensión Jurídica 10, Facultad de Derecho Universidad de los Andes, 2005) p. 111.

36 CORRAL (n, 6), p. 223.

37 Ídem, p. 102.
} 
bles si se exige demostrar la culpa de algún individuo. De esta forma, esta responsabilidad aparece vinculada a ciertos presupuestos que la hacen viable: $1^{\circ}$ que el agente responsable sea fácilmente identificable; $2^{\circ}$ que se exija a todos los posibles responsables un seguro obligatorio; $3^{\circ}$ que las indemnizaciones tengan máximos fijados legalmente (tarificación de las indemnizaciones); $4^{\circ}$ que el daño se produzca en un círculo de actividad determinada, y $5^{\circ}$ que se establezcan causales objetivas de exoneración, como el caso fortuito, la culpa exclusiva de la víctima, y otras ${ }^{58}$.

\section{b) Moderada con formas de limitación de la responsabilidad}

Además de su aplicación sectorial, el modelo de la responsabilidad objetiva suele ser moderado con ciertas formas de limitación de la responsabilidad. Esto porque a la responsabilidad objetiva se le considera una fórmula normal, e injusta, pues el causante del daño debe responder aunque dicho perjuicio se haya producido sin culpa ${ }^{59}$.

Se mencionan como mitigaciones a la responsabilidad objetiva la tarificación o limitación del monto de la indemnización reclamable, la obligatoriedad en la constitución de seguros, la constitución de fondos de limitación de responsabilidad o de garantía y la consideración de causas especiales de exoneración ${ }^{60}$ :

\section{(b.a.) Tarificación de la indemnización reclamable}

Frecuentemente, cada vez que el legislador ha objetivado la responsabilidad, ha fijado un límite de los perjuicios que se indemnizarán ${ }^{61}$, a tal

Ídem, p. 101.

YUSEFF (n. 10), p. 209.

CORRAL (n. 6), p. 221; YUSEFF (n. 10), pp. 209-215.

V.g., en la Ley sobre Protección Agrícola, se establece que el afectado por trabajos realizados por el Servicio Agrícola y Ganadero o tercero designados por este, solo podrá reclamar judicialmente el daño emergente ocasionado: "Si con motivo de los trabajos realizados por el Servicio o por terceros a quienes este haya designado se produjeren perjuicios en bienes u objetos anexos y diversos de los sometidos a tratamiento, ya sea en forma accidental o como consecuencia inevitable de medidas decretadas, el afectado podrá reclamar judicialmente al Servicio únicamente la indemnización del daño emergente ocasionado". (Artículo $8^{\circ}$ Decreto Ley ${ }^{\circ} 3.5 .57$ que establece disposiciones sobre protección agrícola, publicado en el Diario Oficial el 9 de febrero de 1981). Lo propio ocurre en la responsabilidad aeronáutica donde se contempla una responsabilidad objetiva con límites de indemnización para daños que sufran los pasajeros, la carga o terceros en la superficie. Vid. Código Aeronáutico, Ley n ${ }^{\circ}$ 18.916, publicado en el Diario Oficial el 8 de febrero de 1990, Título IX De la responsabilidad aeronáutica, artículos 142 a 175 . En cuanto a la responsabilidad por daños nucleares, Vid. Título V De la responsabilidad civil por daños nucleares, de la Ley de Seguridad Nuclear, $\mathrm{n}^{\circ}$ 18.302, publicada en el Diario Oficial el 2 de mayo de 1984, especialmente artículo 60. Respecto a la responsabilidad deriva de los daños causados por derrames de sustancias nocivas en el mar, Vid. Párrafo 1 Del derrame de bidrocarburos y otras 
grado que puede afirmarse que estas son dos políticas que juegan simultáneamente, una a favor de la víctima y la otra, más bien, en protección del hechor $^{62}$; se protege a los ciudadanos frente a las actividades que pueden ser peligrosas, y al mismo tiempo, se evita que el causante del daño inocente pueda ver comprometido ilimitadamente su patrimonio ${ }^{63}$.

Sin embargo, el establecer límites máximos al monto de las indemnizaciones, además de mitigar la responsabilidad objetiva ${ }^{64}$, tiene por propósito asegurar a la víctima el resarcimiento, pues así se garantiza que el autor del daño se encontrará en condiciones de indemnizar a las víctimas $^{65}$. Y, por otra parte, se logra, evitar lo aleatorio y contingente de una avaluación judicial de los perjuicios ${ }^{66}$.

\section{(b.b.) Constitución de seguros obligatorios}

Si bien la tarificación de las indemnizaciones y los seguros obligatorios son mecanismos independientes entre sí, pudiendo operar uno y otro separadamente, generalmente forman una trilogía: responsabilidad objetiva, limitación cuantitativa y seguro forzoso ${ }^{67}$, con el propósito de asegurar a la víctima el acceder a la reparación del daño sufrido ${ }^{68}$.

Es usual esta figura desde que la sola imposición de la responsabilidad objetiva no es garantía suficiente de que se obtendrá una indemnización, pues la insolvencia del causante del daño puede frustrar los propósitos resarcitorios de la víctima ${ }^{69}$. Así, por ejemplo, en España, y en Europa, al igual que en $\mathrm{Chile}^{70}$, la responsabilidad objetiva por los acci-

substancias nocivas, Título IX De la contaminación, del Decreto Ley $\mathrm{n}^{\circ} 2.222$ que sustituye la Ley de Navegación, publicado en el Diario Oficial el 31 de mayo de 1978, especialmente artículo 145 .

TOMASEllo (n. 2), p. 69.

YUSEFF (n. 10), p. 210.

BiAnCA, Cesare Massimo: "Supervivencia de la teoría de la culpa" (Traducido por Alberto Bueres) en Bueres, Alberto y Kemelmajer de Carlucci, Aída (directores): Responsabilidad por daños en el tercer milenio: bomenaje al profesor doctor Atilio Aníbal Alterini (Buenos Aires, Abeledo - Perrot, 1997) p. 139, señala que la tendencia a compensar el riesgo atribuido al responsable con la limitación del monto resarcible, es un elemento que reduce el ámbito de la responsabilidad objeriva, y que confirma su incapacidad para imponerse como regla general que sustituya la responsabilidad por culpa.

YUSEFF (n, 10), p. 213 advierte que "la sola imposición de la responsabilidad no es garantía suficiente de que se obtendrá una indemnización, ya que la insolvencia del responsable puede frustrar sus propósitos".

TOMASELLO (n, 2), p. 69.

YUSEFF (n. 10), p. 210; asimismo v.g., Ley de seguridad nuclear (n. 61), especialmente respecto a la mencionada trilogía, artículos 49, 60 y 62; Ley de Navegación (n. 61), artículos 145 y 146.

Cfr. Acosta (n. 1), p. 33; TOMAsello (n. 2), p. 70.

YUSEFF (n. 10), p. 213.

Vid. Ley que establece seguro obligatorio de accidentes personales causados por circulación de vebículos motorizados, $\mathrm{n}^{\circ} 18.940$, publicada en el Diario Oficial el 4 de enero de 1986 y sus modificaciones posteriores. 
dentes causados por los automóviles, va acompañada por un sistema de seguro obligatorio, pues si no ocurriera así la indemnidad del peatón dependería de si el automovilista que le atropella es rico o pobre, lo cual no es aceptable, pues se debe garantizar la indemnidad a todos los ciudadanos ${ }^{71}$.

De esta forma, la obligación de constituir un seguro de responsabilidad civil es un mecanismo complementario a la responsabilidad objetiva, el cual tiende al aseguramiento de la víctima, al soportar el pago de la indemnización quien está en mejores condiciones económicas: el asegurador $^{72}$.

Por otro lado, se debe destacar que estos seguros previstos en las leyes que amparan un fundamento objetivo de la responsabilidad, son forzosos, es decir, el asegurado está obligado a contratar, pues le viene impuesto por la ley. De esta forma, el seguro enfatiza el fundamento objetivo de la responsabilidad, en las leyes especiales, pues hacen desaparecer toda idea de culpa, sustituyéndola por una idea de garantía para la víctima; todo eventual daño que se produzca será indemnizado por estar cubierto por la póliza del seguro ${ }^{73}$.

Además, a través del seguro se socializan los riesgos ${ }^{74}$, así se vislumbra su semejanza con la seguridad social: todos aquellos que desarrollan una actividad determinada contribuyen a través de sus cotizaciones (primas) a solventar los daños que se ocasionen en el ámbito de dicha actividad $^{75}$.

\section{(b.c.) Constitución de fondos de limitación de responsabilidad}

Los fondos de limitación de responsabilidad constituyen otra forma de morigeración de la responsabilidad objetiva. Al respecto, se debe tener presente, que si bien existen numerosos supuestos en que se puede limitar la responsabilidad, no en todos ellos se puede constituir estos fondos

\footnotetext{
"En materia de accidentes del tránsito, debido a la frecuencia con que ocurren y al costo social involucrado, el legislador ha contemplado la obligatoriedad de contratar un seguro por el riesgo de accidentes personales. Este seguro cubre en parte los daños personales ocasionados por un accidente, pues el monto de la indemnización que se paga está limitada; limitación que se refiere a la cantidad que debe pagar el seguro, ya que la responsabilidad del sujeto responsable no está limitada". Yuseff (n. 10), p. 258 y 259 ,

7 Cavanillas Mújica, Santiago: "Tendencias en materia de responsabilidad civil" en $\mathrm{M}^{\mathrm{C}-}$ KAY ALLIENDE, Federico (editor): Responsabilidad civil del empresario (Santiago, Cuadernos de Extensión 1, Facultad de Derecho Universidad de los Andes, 1996) p. 14.

72 Cfr. Dízz-PiCAzo (n. 1), p. 736; Molinari (n. 1), pp. 49-51.

Cfr. DOMínguez (n. 1), pp. 126 y 127.

Se trataría de una garantía colectiva: "La colectividad de posibles causantes de daños, hace posible la indemnización de todas las víctimas eventuales de accidentes". YUSEFF (n. 10), p. 214 .

75. Cfr. Díez-Picazo (n. 1), p. 736; Yuseff (n. 10), p. 214.
} 
y, por otro lado, solo se pueden constituir en los casos en que se puede limitar la responsabilidad ${ }^{76}$.

Las normas que autorizan la constitución de dichos fondos en el Derecho chileno se encuentran en la navegación y comercio marítimos ${ }^{77}$, y en los casos de contaminación por hidrocarburos u otras sustancias nocivas en el $\operatorname{mar}^{78}$. En estas normas existen casos en los cuales se puede limitar la responsabilidad, si a quien la ley le atribuye la responsabilidad por el daño desea hacer uso de estas limitaciones, ante el tribunal señalado por la ley, puede constituir un fondo en dinero o mediante garantía, de manera tal que la víctima se pague con ese fondo y se suspenda toda ejecución en su patrimonio individual ${ }^{79}$.

De esta forma, estos fondos de limitación de responsabilidad serían una excepción a lo que se conoce como prenda general de los acreedores, pues el acreedor (víctima que sufre el daño) no puede perseguir la satisfacción de su crédito sobre la totalidad del patrimonio del deudor (a quien la ley atribuye responsabilidad) ${ }^{80}$.

\section{(b.d.) Causas especiales de exoneración de responsabilidad}

La propia ley se encarga de señalar para cada caso cuáles son estas causales especiales de exoneración de responsabilidad. Entre otras, se mencionan: el caso fortuito, la fuerza mayor, la culpa de la víctima, las guerras y subversiones.

En la Ley de Seguridad Nuclear ${ }^{81}$, por ejemplo, se establece expresamente que el explotador de una instalación o establecimiento nuclear, será responsable siempre del caso fortuito y de la fuerza mayor, solo quedan exceptuados los daños nucleares producidos por conflicto $\operatorname{armado}^{82}$.

77 Responsabilidad del armador y del transportador marítimo, Vid. artículos 1210 a 1230 en concordancia con los artículos 897 y 904 del Código de Comercio, Convenciones de Bruselas de 1957 y de Londres de 1976.

Vid. Artículo 145 de la Ley de Navegación (n. 61), y Convenio internacional sobre responsabilidad civil por daños causados por la contaminación de las aguas del mar por hidrocarburos de 1969, publicado en el Diario Oficial el 8 de octubre de 1997.

Vid. Ley de Seguridad Nuclear (n. 61), especialmente respecto a las exenciones de responsabilidad a que puede acogerse el explotador nuclear, artículos 56 a 59.

"La rigidez de esta solución está determinada por el riesgo de la actividad desarrollada, que debe llevar al explotador a tomar todo resguardo posible, incluso contra un desastre natural o intento de sabotaje, por ejemplo." YUSEFF (n. 10), p. 227.
} 
Por su parte, en la Ley de Accidentes del Trabajo ${ }^{83}$ no se indemnizan los accidentes producidos intencionalmente por la víctima ${ }^{84}$; interesa establecer cuándo el perjuicio puede entenderse auotoinferido, pues resulta injusto que otro indemnice si el daño se lo ha generado la propia víctima ${ }^{85}$.

En materia aeronáutica, se libera de responsabilidad al explotador respecto a los daños causados en la superficie, si este ha sido privado del uso de la aeronave por acto de la autoridad, cuando los daños son consecuencia directa de un acto de guerra o de un conflicto armado, cuando son causados por un acto de sabotaje o con ocasión del apoderamiento ilícito de la aeronave ${ }^{86}$.

En estos casos, a quien la ley atribuye la obligación de pagar de la indemnización por el perjuicio causado, la libera de esta carga, porque se destruye el nexo causal entre acción dañina y el daño mismo. En efecto, el caso fortuito, la fuerza mayor, los conflictos armados y la intervención culposa de la víctima, contienen elementos de extraneidad, irresistibilidad e imprevisibilidad ${ }^{87}$.

\section{c) La responsabilidad subjetiva opera como sistema subsidiario}

Se estima que el régimen de la responsabilidad por culpa continúa teniendo vigencia, la culpa siempre permanece, incluso en estos sectores conformados por normas especiales, como sistema subsidiario para cuando no pueda operar el de responsabilidad objetiva ${ }^{88}$, por ejemplo, es habitual, como se escribe más arriba, que las normas de responsabilidad objetiva vayan acompañadas de una limitación de indemnización, pues bien, para demandar indemnizaciones mayores a la cuantía máxima legalmente determinada, está la llamada responsabilidad por culpa ${ }^{89}$, es decir,

83 Ley $\mathrm{n}^{\circ} 16.744$, Que establece normas sobre accidentes del trabajo y enfermedades profesionales, publicada en el Diario Oficial el 1 de febrero de 1968, y sus posteriores modificaciones. Sobre el tema, Vid. BARAONA GONZÁlez, Jorge: "La culpa de la víctima en los accidentes del crabajo: dogmática y jurisprudencia chilenas" en BARAONA GONZÁLEZ, Jorge y ZELAYA ETCHEGARAY, Pedro (editores): La responsabilidad por accidentes del trabajo (Santiago, Cuadernos de Extensión Jurídica 10, Facultad de Derecho Universidad de los Andes, 2005) pp. 123-153.

85 Cfr. RODRÍGUEZ (n. 16), p. 409.

86 Vid. artículos 155 y 156 del Código Aeronáutico (n. 61).

Cfr. Acosta (n. 1), p. 32 y 33; Rodríguez (n. 16) p. 308; Baraona GonzÁlez, Jorge: "Responsabilidad contractual y factores de imputación de daños: apuntes para una relectura en clave objetiva" en Revista Cbilena de Derecho, volumen $24 \mathrm{n}^{\circ} 1$, año 1997, p. 175. "(...) los paliativos de la responsabilidad objetiva son importantes y necesarios, pero deben cubrir solo áreas en las que dicha responsabilidad es factible, y siempre permaneciendo como referente general y mecanismo supletorio el de la responsabilidad por culpa." Corral (n. 6), p. 219; Cfr. YusefF (n. 10), p. 210. 
acreditando culpa o dolo se puede pretender una indemnización de la integridad de los perjuicios sufridos 90 .

En ciertas leyes, esto se recoge expresamente, por ejemplo, en la Ley de Navegación, si ha concurrido efectivamente culpa o dolo, la limitación de la indemnización no procede ${ }^{91}$; en la Ley de Accidentes del Trabajo y Enfermedades profesionales si el accidente se debe a culpa o dolo del empleador o de un tercero, la víctima podrá reclamar contra ellos otras indemnizaciones al as que tenga derecho de acuerdo al derecho común, incluso el daño moral ${ }^{92}$.

\subsection{Sectores de daños}

A fin de agrupar la legislación chilena complementaria más representativa que recoge la responsabilidad objetiva, se siguen los dos grandes grupos definitorios de daños ideados por Santiago Cavanillas Múji$\mathrm{ca}^{93}$ : en la empresa, como actividad productiva organizada; $y$, en actividades que se relacionan con cosas naturalmente peligrosas ${ }^{94}$.

\section{a) En la empresa, como actividad productiva organizada}

\section{(a.a.) Accidentes laborales}

Este sector fue el primero en el tiempo en quedar sujeto a reglas objetivas, tanto en Chile como en el resto del mundo 95 . Antes que exis-

$90 \quad \operatorname{Acosta}(\mathrm{n}, 1)$, p. 33.

91 Vid. artículos 144 a 148 de la mencionada Ley (n. 61), en los cuales se limita la responsabilidad del propietario, armador u operador de la nave "por los perjuicios derivados de cada siniestro hasta un máximo equivalente en moneda nacional a dos mil francos por tonelada de registro de la nave o artefacto naval causante de los perjuicios, y no excede en ningún caso del equivalente de doscientos diez millones de franco". Pero se añade que "si el siniestro ha sido causado por falta o culpa del propietario, naviero u operador, perderá el derecho a la limitación de responsabilidad establecida".

Domínguez Águila, Ramón: "Responsabilidad civil del empresario por el daño moral ocasionado a sus trabajadores" en M'KAY ALLIENDE, Federico (editor): Responsabilidad civil del empresario (Santiago, Cuaderno de Extensión 1, Facultad de Derecho Universidad de los Andes, 1996) p. 28.

Vid. Artículo 69 de la mencionada Ley (n. 83).

93 Doctor en Derecho por la Universidad de Granada, profesor en España.

94 "Actualmente, la tendencia es la objetivación, es decir, la eliminación de la culpa como hecho constitutivo de la responsabilidad de determinados sectores del daño. No se trata de la objetivación de la responsabilidad en ningún Derecho, de modo absoluto y definitivo. Es difícil definir los determinados sectores del daño, pues no en todos los Derechos son los mismos; pero se podrían señalar dos grupos definitorios: En la empresa, como actividad productiva organizada, y en actividades que se relacionan con cosas naturalmente peligrosas". Cavanillas (n. 71), pp. 12 y 13.

95 Para más detalle Vid. Acosta (n. 1), p. 6; Celis (n. 1), p. 50; Díez-Picazo (n. 1), p. 732; DOMinguez (n. 1), p. 115; DUCCI (n. 1), Pp. 38-41; LOPEZ (n. 1), p. 151; VAZQUEZ (n. 1), p. 39; YusefF (n. 10), p. 163; NAVARReTe (n. 12), p. 163. 
tiera una legislación especial sobre la materia, la teoría subjetiva fue criticada debido a la dificultad y a veces la imposibilidad de probar la culpa del autor del daño en relación a los accidentes del trabajo ${ }^{96}$, así se instaura una etapa en la cual el fundamento de la responsabilidad es objetiva, no importa la culpa o negligencia del empleador sino solo el resultado dañoso, sin embargo, el sistema evolucionó rápidamente hacia un modelo de seguro obligatorio y por tanto de seguridad social, escapándose así de los márgenes del derecho privado ${ }^{97}$. Por tanto, en estricto rigor no estamos hoy frente a un caso de responsabilidad objetiva, sino en un modelo de sistema de seguridad social, gestionado por entidades privadas $^{98}$. Sin embargo, se ha considerado relevante incorporarlo en esta clasificación, pues históricamente es el ámbito en el cual se comienza a desarrollar la teoría del riesgo, como se explica en el punto I, de este artículo 99 .

Así, en Chile, actualmente, el daño que ocasiona el accidente del trabajo queda sujeto el régimen de la Ley $\mathrm{n}^{\circ} 16.744^{100}$, la cual contiene un sistema automático y objetivo de reparación del daño, dentro de un modelo de sistema de seguridad social.

\section{(a.b.) Daños al medio ambiente}

Se ha incluido el daño producido al medio ambiente, pues en la mayoría de los casos se trata de una contaminación industrial, y por tanto de daños causados a terceros en la explotación de los medios de producción empresarial.

Leyes más representativas que recogen un fundamento objetivo de la responsabilidad, en materia de contaminación, son: la Ley sobre Protec-

96 Cfr. idem, p. 32 y Navarrete (n. 12), p. 163; Por su parte Abeliuk (n. 1), p. 171, indica que a la responsabilidad subjetiva se le ha criticado entre otras razones, por una cuestión de justicia social; "(...) los obreros quedaban prácticamente desamparados para luchar en pleitos largo y engorrosos con las empresas. Generalmente la víctima es de menos recursos que el autor del daño, y el legislador debe protegerla".

97 CORRAL (n. 6), p. 89. Señala ABELIUK (n. 1), p. 175, "los accidentes del trabajo influyeron en el nacimiento de la responsabilidad por riesgo creado, y hay ahora una tendencia a desplazarlos hacia la seguridad social, mediante la obligatoriedad del seguro a favor de terceros, o la creación de fondos por aportes de las empresas a fin de afrontar las indemnizaciones sin necesidad de juicio declarativo previo". Cfr. Corral (n. 6), p. 251; Domínguez (n. 1), p. 128; Zelaya (n. 54), p. 102.

Una síntesis de la evolución de la legislación chilena en materia de accidentes del trabajo, distinguiendo tres etapas: aplicación de las normas clásicas sobre responsabilidad subjetiva, responsabilidad sin culpa u objetiva, y responsabilidad social se encuentra en GUMUCIO RIVAS, Juan Esteban: "Ruptura del concepto clásico de responsabilidad civil en materia de accidentes del trabajo. Evolución de la legislación chilena" en Revista Laboral Chilena, volumen $8 \mathrm{n}^{\circ} 12$, Dic. 1998, pp. 75-82. 
ción Agrícola ${ }^{101}$, la Ley de Seguridad Nuclear ${ }^{102}$, la Ley que Crea un Sistema Nacional de Áreas Silvestres Protegidas del Estado ${ }^{103}$, la Ley de Navegación ${ }^{104}$ que trata de de daños causados por derrames de sustancias nocivas en el mar.

En la legislación europea sobre responsabilidad civil por daño al medio ambiente, existe un modelo objetivo diseñado por la Ley de Responsabilidad Ambiental alemana ${ }^{105}$, pero la mayoría de las otras legislaciones europeas mantienen un régimen de responsabilidad subjetiva, exigiendo la acreditación de dolo o culpa en el imputado. Sin embargo, en Francia y España ${ }^{106}$ se tiende a objetivar esta responsabilidad, por obra de la doctrina y cierta jurisprudencia, que operan interpretando extensivamente disposiciones legales presentes en los Códigos Civiles, tomando para ello en cuenta la teoría del riesgo empresa o la distribución social de los daños ${ }^{107}$.

\section{(a.c.) Daños debidos a productos defectuosos}

En la producción misma se establecen corrientemente, en Europa y en América, reglas de responsabilidad objetiva por los daños debido a los defectos de los productos ${ }^{108}$. Esta tendencia surge en Estados Unidos a principios del siglo XX, y ha tenido un gran desarrollo. Y es objetiva en cuanto lo que se debe apreciar es la condición del producto y no la

101

102 Ley de Seguridad Nuclear (n. 61), artículos 49 a 66. En estrecha concordancia con la Convención de Viena sobre Responsabilidad Civil por Daños Nucleares, de 21 de mayo de 1963 , publicada en el Diario Oficial el 8 de marzo de 1990.

103 Vid. Ley $n^{\circ} 18.632$ que Crea un Sistema Nacional de Áreas Silvestres Protegidas, publicada en el Diario Oficial el 27 de diciembre de 1984, especialmente, sus artículos 25 y 26; se sanciona a quien infrinja la ley con multas y reparación de los daños que hayan ocasionado, sin hacer referencia alguna a culpa o dolo.

104 Vid. Ley de Navegación (n. 61), en donde se contempla una responsabilidad objetiva para el dueño, armador u operador de una nave o artefacto naval que produzca derrames de hidrocarburos u otras sustancias contaminantes en el mar.

105 "Del 10 de diciembre de 1989 , en la cual no se precisa comprobación de dolo o culpa, bastando acreditar el nexo causal". CORRAL TALCIANI, Hernán: "La responsabilidad civil por daño al medio ambiente en la legislación y jurisprudencia de la Unión Europea” en $\mathrm{M}^{\mathrm{C}} \mathrm{KAY}$ AlLIENDE, Federico (editor): Responsabilidad civil del empresario (Santiago, Cuadernos de Extensión 1, Facultad de Derecho Universidad de los Andes, 1996) p. 97.

"Se urilizan normas relativas a la responsabilidad por el hecho de las cosas, artículos 1382 y 1384 del Código Civil francés, y artículos 1902 y 1908 del Código Civil español, por propender a la superación del requisito culpa: se invierte la carga de la prueba, se elevan Ios estándares de diligencia, se considera que la sola existencia del daño da cuenta de la presencia de una culpa, etc.". Ibídem.

Ibídem.

Vid. Corral (n. 6), p. 266; CAVAnillas (n. 71), p. 13; LARroumet, Christian: Responsabilidad civil contractual. Algunos temas modernos (Santiago, Editorial Jurídica de Chile, 1998, 1" edición) pp. 95 y 96; ACosta (n. 1), pp. 28 y 29. 
conducta del fabricante. Además no solo se protege a quien adquirió los productos, sino también a los terceros no contratantes que se veían afectados por el producto en cuestión ${ }^{109}$.

Por su parte, en la Comunidad Europea, el año 1985 se dictó una directiva, a fin de que los países europeos adoptaran una responsabilidad civil objetiva en materia de daños causados por productos defectuosos, bastando probar por la víctima que el daño producido fue ocasionado por el defecto de la cosa, y la atribución subjetiva de la responsabilidad al sujeto demandado, es decir, por ejemplo, que el demandado es el fabricante del producto defectuoso ${ }^{110}$.

En nuestro Derecho, la materia se trata en la Ley de Protección al Consumidor ${ }^{111}$, sin embargo, no es claro cuál es el fundamento de la responsabilidad que se recoge. Más bien establece un derecho optativo para exigir la reparación, reposición o devolución del precio en ciertos casos señalados en su artículo $20^{112}$. Cabe hacer notar, que antes de la promul-

109 Para más detalles acerca de la responsabilidad contractual y extracontractual en materia de productos defectuosos en Estados Unidos, se puede consultar López (n. 1), pp. 153157, en el párrafo ideas extractadas de pp. 153 y 154.

110 Cfr. LOPEZ (n. 1), pp. 157 y 158; Para detalles al respecto, especialmente del caso en España, Vid. CaVAnillas Mujica, Santiago: "Responsabilidad por productos defectuosos en la Unión Europea" en Mckay Alliende, Federico (editor): Responsabilidad civil del empresario (Santiago, Cuadernos de Extensión 1, Facultad de Derecho Universidad de los Andes, 1996) pp. 133 a 143.

11 Vid. Ley $n^{\circ} 19.496$, publicada en el Diario Oficial el 7 de marzo de 1997, modificada por la Ley $n^{\circ} 19.955$, publicada en el Diario Oficial el 14 de julio de 2004, especialmente Párrafo $5^{\circ}$ Responsabilidad por incumplimiento, artículos 20 a 22.

112 LÓPEZ (n. 1), p. 165, sostiene que no es objetiva, en virtud del inciso primero del artículo 23 de la ley que se halla en el mismo párrafo en el cual está inserto el artículo 20 , pues dice que comete infracción a la ley el proveedor que, en la venta de un bien o en la prestación de un servicio, actuando con negligencia, causa menoscabo al consumidor. Por otra parte, la Ley en el artículo 47 trata de los daños causados por productos oficialmente declarados peligrosos, donde el régimen sería el de una culpa presunta, pues permite la exoneración cuando se acredite debida diligencia por parte de los sujetos a los cuales la ley les atribuye la responsabilidad. Mientras que CORRAL TALCIANI, Hernán: "Ley de protección al consumidor y responsabilidad civil por productos y servicios defectuosos" en Corral TALCiAnI, Hernán (editor): Derecho del consumo y proteción al consumidor (Santiago, Cuadernos de Extensión, Universidad de los Andes, 1999) p. 179 , señala que el legislador no precisa el fundamento de la responsabilidad en la Ley especial en comento, y si se constata de que se trata de una responsabilidad de índole contractual se debería concluir, que aplicando el artículo 1.547 del Código Civil, se estaría ante un régimen de culpa presunta: el proveedor responde a menos que pueda acreditar que el daño no se debe a su negligencia. No obstante, agrega, p. 180, existe constancia que en el proceso legislativo existía la intención de objetivar la responsabilidad del proveedor. Y por tanto, habría que distinguir entre el derecho opcional y la indemnización de perjuicios: Tratándose del derecho opcional, el tenor imperativo de las normas debe llevar a la conclusión de que no se admite la alegación de caso fortuito o de ausencia de culpa del proveedor. Así, respecto de la devolución o imputación del precio, reposición o reparación del producto se ha consagrado una responsabilidad objetiva. Respecto de la obligación anexa al derecho opcional de resarcir los 
gación de la ley en comento -año 1997-, la reparación de los perjuicios causados por productos dañosos era un tema desconocido en nuestro Derecho $^{113}$. Sin embargo, de lege ferenda, sería deseable una determinación del fundamento de la responsabilidad en esta materia por parte del legislador.

\section{(a.d.) Responsabilidad de las empresas y servicios públicos}

Por otra parte al referirse a empresa, no solo se hace alusión a las mercantiles, sino también a la administración pública, en este sector se incluye entonces la responsabilidad por el funcionamiento de los servicios públicos, de carácter objetivo en Europa ${ }^{114}$.

En Chile así lo ha confirmado la jurisprudencia ${ }^{115}$, pues indica existe la "posibilidad que el Estado administrador pueda igualmente ser obligado a responder por cualquier lesión causada en bienes o derechos de particulares en supuestos de actividades peligrosas o como consecuencia de riesgos de carácter grave, que el legislador ha estimado necesario indemnizar, exigiendo la concurrencia de una simple relación de causalidad material entre el hecho u omisión imputable a un órgano administrativo y el resultado producido" 116

perjuicios que provienen del incumplimiento contractual, a falta de declaración expresa de la ley, procede aplicar las reglas de la responsabilidad contractual, por tanto procede admitir la alegacíón del caso forruito o la debida diligencia del proveedor. Por su parte, Zelaya Etchegaray, Pedro: "El cúmulo u opción de responsabilidades en la nueva ley de protección al consumidor" en CORRal TALCiani, Hernán (editor): Derecho del consumo y protección al consumidor (Santiago, Cuadernos de Extensión, Universidad de los Andes, 1999) p. 229, también considera que la acción de indemnización se funda en la responsabilidad subjetiva del demandado, por tanto siempre podrá exonerarse probando que obró con la debida diligencia o que el daño se ha debido a caso fortuito o culpa exclusiva de la víctima (consumidor).

113 Cfr. DOMínguez (n. 1), p. 107 y 109; LÓPeZ (n. 1) p. 162-163.

114 Cavanillas (n, 71), p, 13.

115 Vid, v.g. Considerando $10^{\circ}$, Corte Suprema, 15 de mayo de 2002 , en Gaceta Juridica n ${ }^{\circ}$ 263, p. 29: "el ordenamiento jurídico no encierra disposiciones de carácter general que establezcan responsabilidades objetivas para los particulares o el Estado y que, por ende, esta clase de responsabilidad requiere de una declaración explícita del legislador que describa las circunstancias precisas que pueden generarla, como ocurre, por excepción, v.g., en las situaciones descritas en los artículos 2327 y 2328 del Código Civil y 155 del Código Aeronáutico. En el caso del Estado y sus organismos, entre otras, en las señaladas en los artículos 21 del Código de Minería, $8^{\circ}$ del decreto ley $\mathrm{N}^{\circ} 3.557$, de 1981; 50 y 52 de la ley $\mathrm{N}^{\circ} 18.302,17$ de la ley $\mathrm{N}^{\circ} 18.415$ y 52 de la ley $\mathrm{N}^{\circ} 19.300$ y 174 de la ley $\mathrm{N}^{\circ} 18.390$, modificado por el $\mathrm{N}^{\circ} 35$ del artículo $1^{\circ}$ de la ley $\mathrm{N}^{\circ} 19,495$, si bien esta última norma de la Ley del Tránsito establece propiamente una presunción de responsabilidad".

116 Considerando $7^{\circ}$ y $8^{\circ}$, Corte de Apelaciones de Santiago, 21 de noviembre de 2003 , en Gaceta Jurídica $\mathrm{n}^{\circ} 281$, p. 122. 
Sin embargo, cabe hacer notar al respecto que los profesores de Derecho Administrativo chilenos ${ }^{117}$, no están de acuerdo acerca de si la responsabilidad del Estado es objetiva o no, lo que ha llevado a la disparidad de criterios en Tribunales, fundamentalmente respecto a la responsabilidad del Estado por actos realizados por sus agentes, y en la responsabilidad del Estado por falta de servicio ${ }^{118}$.

Por ejemplo, el profesor PIERRY ARRAU cree que el problema es más bien una cuestión terminológica que de fondo, en efecto, indica que si por responsabilidad objetiva se entiende que no hay que probar culpa o dolo de funcionario alguno, entonces es objetiva, sin embargo, no se puede olvidar que en la responsabilidad objetiva lo fundamental es que no hay necesidad de una conducta reprochable, y en el caso de la falta de servicio sí existe un juicio de imputabilidad, pues se debe probar que el servicio no funcionó como se suponía que debía hacerlo, siendo esta falta la causa del daño. En otras palabras, no interesa la persona del funcionario, el que podrá estar o no identificado, lo que interesa es la falta de servicio, lo cual implica un juicio de un reproche o reparo de ilegitimidad ${ }^{119}$.

En cambio, el profesor SOTO KLOSS sostiene que la responsabilidad del Estado -en cualquiera de las funciones o actividades que asume- es una responsabilidad objetiva, pues al ser una persona jurídica, es imposible estructurarla técnicamente sobre la base de culpa o dolo, sino se funda en un daño antijurídico (que la víctima no estaba jurídicamente obligada a soportar) producido por un órgano del Estado en el ejercicio de sus funciones ${ }^{120}$. Es decir, califica, sin ambigüedad la responsabilidad por falta de servicio como una responsabilidad objetiva, en la que no tiene injerencia la reprochabilidad: la culpa o el dolo ${ }^{121}$.

117 Se pueden mencionar como partidarios de una responsabilidad objetiva del Estado a los profesores Eduardo Soto Kloss, Hugo Caldera Delgado y Enrique Silva Cimma; y entre quienes discrepan de esta opinión a los profesores Álvaro QUINTANILLA y PIERRY ARRAU.

118 V.g. vid. Quezada Salazar y otros con Fisco de Cbile (2005): Corte Suprema, 19 de octubre de 2005, en LexisNexis 33059; Corte de Apelaciones de Santiago, 4 de marzo de 2005, en Gaceta Jurídica, $\mathrm{n}^{\circ} 297$, p. 75 ; Corte de Apelaciones de Santiago, 16 de diciembre de 2002 , en Gaceta jurídica, n 270, p. 96. En sentido contrario, Corte de Apelaciones de Santiago, 11 de enero de 2006, en Gaceta Jurídica, $\mathrm{n}^{\circ} 307$, p. 78 ; Rebolledo Rojas y otra con Fisco de Chile (2004); Corte Suprema, 29 de septiembre de 2004, en LexisNexis 30934; Corral (n. 6), p. 224, 301-311; Pierry Arrau, Pedro: “¿Es objetiva la responsabilidad del Estado? Estado actual de la jurisprudencia" en Revista de Derecho del Consejo de Defensa del Estado n ${ }^{\circ} 11$ junio 2004 (Santiago, Consejo de Defensa del Estado, 2004) p. 11; LÓPEZ SANTA MARÍA, Jorge: "La responsabilidad patrimonial por falta de servicio. Casuística chilena reciente" en Responsabilidad por daños en el tercer milenio: bomenaje al profesor doctor Atilio Aníbal Alterini (Buenos Aires, Abeledo - Perror, 1997) p. 483-491. PIERRY (n. 118), pP. 12-15.

120 Soto KLoss, Eduardo: II Derecho Administrativo. Bases fundamentales, El principio de juridicidad (Santiago, Editorial Jurídica de Chile, 1996, 1" edición) pp. 309 y 310. LÓPEZ (n. 118), p. 481. 
En resumen, en Chile, en la esfera de responsabilidad del Estado por falta de servicio, no se sabe con certeza si es propiamente un campo de responsabilidad objetiva. Algunos autores sostienen se trataría de una responsabilidad objetiva, otros discrepan de esta opinión. El resultado de ello es la existencia de jurisprudencia en ambos sentidos ${ }^{122}$.

\section{b) En actividades que se relacionan con cosas naturalmente peligrosas}

Se debe enfatizar el que estas actividades sean "naturalmente peligrosas", pues es necesaria esta distinción, desde que todas las actividades humanas contienen en sí mismas un grado más o menos elevado de peligrosidad para quienes directamente las ejercen o para los terceros extraños a ellas. Se ha de diferenciar, de esta forma, una actividad normalmente inocua que presenta los caracteres de la peligrosidad de la conducta imprudente o negligente del que la ejercita, de una actividad que en sí misma es potencialmente dañosa por el alto porcentaje de siniestros que puede causar por su naturaleza o por la naturaleza de los medios empleados ${ }^{123}$.

\section{(b.a.) Daños causados por vehículos motorizados}

En cuanto a la responsabilidad por daños causados por vehículos motorizados ${ }^{124}$, el legislador ha establecido un caso de responsabilidad por el hecho ajeno sobre una base objetiva, esto es, el dueño del vehículo -o el tenedor de él a cualquier título- es responsable solidario con el conductor del mismo, de los daños y perjuicios que se ocasionen con motivo del uso del automóvil ${ }^{125}$, sin que pueda excusarse probando falta de culpa.

122 Cfr. López (n. 1), p. 150 y 151; Martínez Estay, José Ignacio: "La responsabilidad patrimonial del Estado por infracción al principio de igualdad y al derecho de propiedad en el derecho público chileno" en AA.VV.: Derecho de daños (Santiago, LexisNexis, 2002), pP. 192-195.

123 Cfr. Franzoni, Massimo: "La actividad peligrosa" (Traducido por Alberto Bueres) en Bueres, Alberto y Kemelmajer de Carlucci, Aída (directores): Responsabilidad por daños en el tercer milenio: bomenaje al profesor doctor Atilio Aníbal Alterini (Buenos Aires, Abeledo Perrot, 1997) p. 125.

124 Vid. Ley de Tránsito, $\mathrm{n}^{\circ} 18.290$, publicada en el Diario Oficial el 7 de febrero de 1984, especialmente artículo 174 , modificado por las leyes $\mathrm{n}^{\circ} 19.495 \mathrm{y} \mathrm{n}^{\circ} 20.068$, publicadas en el Diario Oficial el 8 de marzo de 1997 y el 10 de diciembre de 2005, respectivamente.

125 Nuestra jurisprudencia así lo ha confirmado, al indicar que "no es necesario acreditar culpabilidad personal del dueño en relación al daño provocado por el vehículo de su dominio". Vid. v.g. Considerando $1^{\circ}$ y $2^{\circ}$, Corte de Apelaciones de San Miguel, 19 de julio de 1999, en LexisNexis 21559; Considerando $14^{\circ}$, Corte de Apelaciones de San Miguel, 20 de septiembre de 1995, en LexisNexis 21493. Considerando $6^{\circ}$, Corte de Apelaciones de San Miguel, 12 de julio de 1995, en LexisNexis 21481. Considerando $3^{\circ}$, Corte de Apelaciones de Santiago, 22 de abril de 2005, en Gaceta Jurídica, n 298, p. 139. 
Las únicas causales de exoneración son que el vehículo haya sido usado sin su conocimiento o autorización. En otras palabras, siempre responde el dueño del vehículo, a menos que se probare que el vehículo le fue sustraído sin su conocimiento o autorización ${ }^{126}$,

El tener un vehículo constituye un riesgo, lo que se comprueba con solo tener presente las estadísticas anuales de muerte en accidentes de tránsito. Debido a este riesgo, el propietario de un vehículo debe garantizar al resto de las personas que tendrá especial cuidado con su utilización, tanto propia como por parte de otros 127 .

\section{(b.b.) Daños causados por aeronaves}

El Código Aeronáutico ${ }^{128}$ contempla una suerte de responsabilidad objetiva con límites de indemnización y causales específicas de liberación de la obligación de indemnizar, para daños que sufran los pasajeros, la carga o terceros, ocasionados en razón del transporte ${ }^{129}$; o en la superfi$\mathrm{Cie}^{130}$.

Además, se trata del abordaje aéreo, es decir de los daños ocasionados a los pasajeros, cargas o terceros por la colisión de aeronaves, en vuelo o movimiento ${ }^{131}$.

No en todos los casos existe una responsabilidad objetiva, en sentido estricto, por ejemplo, respecto de los daños a los pasajeros derivados del retardo en la ejecución del transporte se está en presencia de un caso de culpa presunta, pues se permite al transportador excusarse probando la debida diligencia ${ }^{132}$. De esta forma, en materia de navegación aeronáutica existe responsabilidad objetiva, pero se encuentra atenuada, pues se permite que en ciertas circunstancias, el explotador se libere de responsabilidad $^{133}$.

Mientras que en la mayoría de las legislaciones extranjeras que contemplan una reglamentación de la navegación aérea establecen la respon-

126 V.g., en tal sentido: Considerando $11^{\circ}$, Corte de Apelaciones de Rancagua, 30 de agosto de 2000, en LexisNexis 23014: “(...) el querellado utilizó el móvil con que se produjo el accidente, sin el conocimiento o autorización expresa o tácita del dueño del vehículo, por lo que es forzoso es concluir que la demanda civil intentada contra esta parte debe ser rechazada".

127 YUSEFF (n. 10), p. 258.

128 Vid. Código Aeronáutico (n. 61).

129 Ídem, artículos 142 a 154.

130 Ídem, artículos 155 a 160.

131 Ídem, artículos 161 a 169.

132 Para detalles acerca del fundamento de la responsabilidad en materia aeronáutica, en las diversas situaciones que se pueden distinguir en el mencionado Código, Vid. TOMASELLO (n. 2), pp. 86 a 88; CORRAl. (n. 6) pp. 261 y 262; YUSEFF (n. 10), pp. 239 a 253; NAVARRete (N. 12), pp. 160-177. Vid. Nota supra 39. 
sabilidad objetiva, pues se encuentra extendida la idea de que constituye una actividad ultraazarosa, es decir, que necesariamente envuelve un riesgo de serio daño que no puede ser eliminado por el ejercicio del mayor cuidado, y no es materia de uso común ${ }^{134}$.

\section{(b.c.) Daños causados por obras de construcción}

En el sector de daños producidos por la actividad de la construcción, Ley General de Urbanismo y Construcciones ${ }^{135}$, establece una normativa especial fundada en responsabilidad objetiva ${ }^{136}$, pues el propietario primer vendedor de la construcción, es responsable por los daños que provengan de fallas o defectos de la misma, sea durante su ejecución o después de terminada, sin ser relevante la circunstancia de haberse conocido o no tales fallas o defectos al momento de contratar, y aunque este principal responsable frente al perjudicado pueda repetir contra el constructor o profesional que haya causado la anomalía constructiva ${ }^{137}$, a la víctima le basta probar la falla o defecto de la construcción, para ser resarcido de los daños y perjuicios por parte del propietario primer vendedor ${ }^{138}$.

Vid. NAVARRete (n. 12), pp. 169-177.

Vid. Artículo 18 de la Ley General de Urbanismo y Construcciones, Decreto con Fuerza de Ley $n^{\circ} 458$, publicado en el Diario Oficial el 13 de abril de 1976, modificado por la Ley 19.472, publicada en el Diario Oficial el 16 de septiembre de 1996. Asimismo, Capítulo 2 De las responsabilidades, de Decreto 47 del Ministerio de Vivienda y Urbanismo, publicado en el Diario Oficial el 5 de junio de 1992, que fija el nuevo texto de la Ordenanza General de la Ley General de Urbanismo y Construcciones, especialmente, su artículo 1.2.3, modificado por el Decreto 173, del mencionado Ministerio, publicado en el Diario Oficial el 12 de marzo de 1997.

La Corte Suprema en sus fallos ha declarado que efectivamente el artículo 18 de la Ley en comento recoge una responsabilidad objetiva, vid. v.g. considerandos $1^{\circ}$ y $4^{\circ}, 29$ octubre 2003, en LexisNexis 28796; considerando $1^{\circ}$ letra f), 10 noviembre de 2005 , en Gaceta Jurídica n ${ }^{\circ} 305$, p. 89. Sin embargo, CORRAL TAlCIANI, Hernán: "Responsabilidad civil extracontractual en la construcción" en Gaceta Jurídica n ${ }^{\circ} 233,1999$, p. 35, sostiene que la normativa no es clara, que la ley diga "será responsable" no indica en forma certera que se trate de una responsabilidad objetiva, perfectamente podría interpretarse como una mera afirmación de responsabilidad conforme a las reglas generales. Luego señala, que solo por la historia de la ley y su finalidad, es posible sostener que existe responsabilidad objeriva tratándose del propietario primer vendedor.

CORRal (n. 6), p. 224; Corral. (n. 136), pp. 33 y 34, enfatiza el interés de la norma por centralizar las acciones que proceden a favor de la víctima en un solo sujeto: el propietario vendedor, de manera tal que el perjudicado se libra de identificar cuál de los intervinientes en el proceso de construcción con su actividad ocasionó el daño. El propietario primer vendedor luego podrá repetir en contra de los proyectistas o constructores, y estos, a su vez, en contra de los subcontratistas, proveedores o fabricantes de materiales, en busca del directamente responsable.

CORRAL (n. 136), p. 34, señala que en el caso de la Ley especial, no es necesario que se pruebe ruina, como exige el Código Civil; basta que el daño se haya producido por fallas o defecros en la construcción. 
Esta Ley, sin embargo, deja vigente la normativa existente en el Código Civil en la materia, artículos $2003 \mathrm{n}^{\circ}$ s 3 y 4, 2004, 2323 y 2324 , que constituyen el régimen común. En efecto, el inciso $3^{\circ}$ del artículo 18 de la Ley, comienza con la frase "Sin perjuicio de lo establecido en el $\mathrm{n}^{\circ}$ 3 del artículo 2003 del Código Civil (...)".

Así pues, existe una evidente intención del legislador de hacer coexistir ambos regímenes de responsabilidad paralelamente en beneficio del perjudicado, quien podrá recurrir a uno u otro, de acuerdo a sus conveniencias $^{139}$.

Las normas del Código Civil se pueden aplicar en el supuesto en que el empresario constructor se encarga de toda la obra por un precio único prefijado, distinguiéndose de la Ley especial en comento, en materia de fundamento de la responsabilidad en: si los materiales han sido proporcionados por el dueño de la obra, existe responsabilidad solo si el constructor por su oficio debía conocer el vicio o si efectivamente lo conoció y no dio oportuno aviso; y solo si la ruina del edificio proviene, no de un vicio constructivo, sino de la negligencia del propietario en su conservación y reparación, el perjudicado puede demandar al propietario. En síntesis, se trataría de un sistema de culpa presunta; la sola comprobación de que la ruina proviene de una falla o vicio en la construcción exime al actor de probar la culpa ${ }^{140}$.

\section{CONCLUSIONES: ESTADO ACTUAL DEL FUNDAMENTO DE LA RESPONSA- BILIDAD EN CHILE Y TENDENCIAS EN EL DERECHO COMPARADO}

1. En Chile, el fundamento de la responsabilidad sigue basado en torno a la culpa; el eje principal del sistema aún es el principio tradicional de "no hay responsabilidad sin culpa", recogido en el Código de Bello.

2. El sistema se ha ido objetivando con variados mecanismos, dentro de los cuales se mencionan en este estudio las presunciones de culpa, las cuales facilitan la tarea probatoria de la víctima. Esto constituye un paso hacia la objetivación, pero no se puede asimilar a la responsabilidad objetiva en sí, pues en esta se prescinde de todo elemento subjetivo, y por ende se excluye todo juicio de reprochabilidad.

3. Actualmente, en Chile, existen regímenes sectoriales de responsabilidad objetiva plasmados en legislación complementaria, pero no abrogan el régimen común del Código Civil, la responsabilidad subjetiva opera incluso en estos sectores de forma subsidiaria. Es más, las leyes complementarias analizadas someramente en este estu-

\footnotetext{
139 CORRAL. (n. 136), p. 41.

140 CORRAL. (n. 136), p. 33.
} 
dio de forma ejemplarizadora, no contemplan en forma exclusiva la responsabilidad objetiva, sino existe mezcla con responsabilidad subjetiva y presunciones de culpa, como ocurre por ejemplo en materia de navegación aeronáutica.

4. El factor de atribución que subyace en estas legislaciones en la mayor parte de los casos es el riesgo creado. En Derecho Comparado, se sabe existen producto de la ley, doctrina y jurisprudencia, otros factores de atribución, pero en Chile no se ha alcanzado tal desarrollo de la responsabilidad objetiva.

5. La mayoría de los autores nacionales, son contrarios a establecer la teoría objetiva como un principio general de justificación de la responsabilidad civil ${ }^{141}$; se sostiene que el único principio general en el que puede descansar la responsabilidad civil, es la culpa ${ }^{142}$. La responsabilidad objetiva cuenta con innegables ventajas sociales, pues protegen a las víctimas de frente a hechos dañosos, facilitando sus reclamaciones en un eventual juicio, pero se critica que llevado a extremo todos podemos ser responsables de cualquier riesgo o peligro, sin que haya mediado culpa o negligencia de nuestra parte ${ }^{143}$.

6. Por su parte, la responsabilidad objetiva no es garantía segura para los perjudicados, pues se pueden ver frustradas sus pretensiones, si quienes resultan ser condenados son insolventes y no pueden económicamente hacerse cargo de las indemnizaciones impuestas ${ }^{144}$. De ahí que sea frecuente que el legislador al regular una materia específica, fundando el deber de reparación en un factor objetivo, exija la constitución de seguros obligatorios.

7. El seguro adquiere tal importancia en el Derecho Comparado-más evolucionado que el nuestro- que la acción de responsabilidad civil prácticamente está cayendo en desuso ante un sistema automático de reparación ${ }^{145}$. Este fuerte predominio de los seguros hace que se

141 Alessandri (n. 1), pp. 119-121; TOMASEllo (n. 2), p. 63 a 68; CORRAL (n. 6), p. 222; YUSEFF (n. 10), pp. 267-273.

142 "De que el sistema de la responsabilidad extracontractual por culpa no puede considerarse caducado, es prueba el Código de Derecho Canónico (1983), que consagra un canon a la materia para recoger solo el viejo principio: "todo aquel que causa a otro un daño ilegítimamente por un acto jurídico o por otro acto realizado con dolo o culpa, está obligado a reparar el daño causado" (canon 128). El Código Civil de Québec de 1994, señala que quien falta al deber de las reglas de conducta es responsable del perjuicio que se causa por "esta culpa" a otro (artículo 1457). En el Proyecto de Código Civil argentino de 1998 se dispone que, a falta de disposición legal o estipulación de las partes, el factor de atribución de la responsabilidad es la culpa (artículo 1602)." CORRAL (n. 6), p. 103. Cfr. Difz-PICAZO (n. 1), pp. 735 y 736.

Cfr. Diez-PICAZO (n. 1), p. 736.

145 Esto ocurre porque, RODRíguez (n. 16), p. 111, el nuevo derecho de daños aspira, fundamentalmente a ampliar la cobertura de los dalos y sus factores de atribución por una parte, y a facilitar a la víctima el acceso a la reparación, por otra. 
llegue a confundir incluso seguro de responsabilidad civil con sistemas de seguridad social. Lo cual ha ocurrido en Chile hasta cierto punto, en materia de accidentes del trabajo.

8. En síntesis, en nuestro Derecho, la culpa ha sido desplazada en algunos casos y atenuada fuertemente en otros, por tanto ya no se la puede considerar como criterio único de fundamentación de la responsabilidad civil, sin embargo, tampoco se pretende llegar al otro extremo, intentando el reemplazo absoluto del criterio tradicional por criterios objetivos ${ }^{146}$.

9. Teoría subjetiva y objetiva de la responsabilidad, lejos de excluirse la una a la otra, se complementan muy bien, la combinación de ambas nos permite acercarnos a un equilibrio entre intereses y derechos, y una adecuada aplicación de ellas nos llevará a obtener resultados más equitativos ${ }^{147}$.

\section{Bibliografía CitAdA}

- Abeliuk Manasevich, René: I Las Obligaciones (Santiago, Editorial Jurídica de Chile, 1993, $3^{a}$ edición).

- Acosta Ramírez, Vicente: "La responsabilidad objetiva" en Cuadernos Jurídicos $n^{\circ} 6$ (Viña del Mar, Facultad de Derecho de la Universidad Adolfo Ibáñez, 1996) pp. 1-36.

- Alessandri Rodríguez, Arturo: De la responsabilidad extracontractual en el Derecho Civil chileno (Santiago, Imprenta Universitaria, 1943).

- BARAONA GONZÁLEZ, Jorge: "Responsabilidad contractual y factores de imputación de daños: apuntes para una relectura en clave objetiva" en Revista Chilena de Derecho, volumen 24 n 1, año 1997 , pp. 151-177.

: "La culpa de la víctima en los accidentes del trabajo: dogmática y jurisprudencia chilenas" en BARAONA GONZÁLEZ, Jorge y Zelaya Etchegaray, Pedro (editores): La responsabilidad por accidentes del trabajo (Santiago, Cuadernos de Extensión Jurídica 10, Facultad de Derecho Universidad de los Andes, 2005) pp. 123-153.

- BIANCA, Cesare Massimo: "Supervivencia de la teoría de la culpa" (Traducido por Alberto Bueres) en Bueres, Alberto y Kemelmajer DE CARLUCCI, Aída (directores): Responsabilidad por daños en el tercer milenio: homenaje al profesor doctor Atilio Aníbal Alterini (Buenos Aires, Abeledo - Perrot, 1997) pp. 137-142.

\footnotetext{
146 YUSEFF (n. 10), p. 270.

147 ALESSANDRI (n. 1), p. 120; YUSEFF (n. 10), p. 194.
} 
- Cavanillas Mújica, Santiago: "Tendencias en materia de responsabilidad civil" en M ${ }^{\mathrm{C}} \mathrm{KAY}$ ALLIENDE, Federico (editor): Responsabilidad civil del empresario (Santiago, Cuadernos de Extensión 1, Facultad de Derecho Universidad de los Andes, 1996) pp. 9-18.

: "Responsabilidad por productos defectuosos en la Unión Europea” en M ${ }^{\mathrm{C}} \mathrm{KAY}$ AlliEnde, Federico (editor): Responsabilidad civil del empresario (Santiago, Cuadernos de Extensión 1, Facultad de Derecho Universidad de los Andes, 1996) pp. 133-143.

- Celis Rodríguez, Rubén: Curso especializado de responsabilidad extracontractual (Santiago, Colección Temas Jurídicos y Sociales $n^{\circ} 2$, Facultad de Ciencias Jurídicas y Sociales Universidad Central de Chile, 2001, $1^{\mathrm{a}}$ edición).

- Corral Talciani, Hernán: Lecciones de responsabilidad civil extracontractual (Santiago, Editorial Jurídica de Chile, 2003, 1ª edición).

: "Ley de protección al consumidor y responsabilidad civil por productos y servicios defectuosos" en CORRAL TALCIANI, Hernán (editor): Derecho del consumo y protección al consumidor (Santiago, Cuadernos de Extensión, Universidad de los Andes, 1999), pp. 163-211.

: "Responsabilidad civil extracontractual en la construcción" en Gaceta Jurídica n² 233, 1999, pp. 31-42.

: "La responsabilidad civil por daño al medio ambiente en la legislación y jurisprudencia de la Unión Europea” en MCKAY Alliende, Federico (editor): Responsabilidad civil del empresario (Santiago, Cuadernos de Extensión 1, Facultad de Derecho Universidad de los Andes, 1996) pp. 83-103.

- Díez-Picazo, Luis: "Responsabilidad civil hoy" en Anuario de Derecho Civil, tomo 32, fascículo IV, octubre-diciembre 1979, pp. 727-738.

- Domínguez ÁGuila, Ramón: “Aspectos contemporáneos de la responsabilidad civil" en Revista de Derecho Universidad de Concepción $\mathrm{n}^{\circ}$ 185, año 1989, pp. 107-139.

: "Responsabilidad civil del empresario por el daño moral ocasionado a sus trabajadores" en Mckay Alliende, Federico (editor): Responsabilidad civil del empresario (Santiago, Cuaderno de Extensión 1, Facultad de Derecho Universidad de los Andes, 1996) pp. 19-33.

- D’ors, Álvaro: Derecho privado romano (Pamplona, Eunsa, 1989, $7^{\mathrm{a}}$ edición).

- Ducci Claro, Carlos: Responsabilidad civil (Santiago, Editorial Jurídica de Chile, 1970).

- FranzONI, Massimo: "La actividad peligrosa" (Traducido por Alberto Bueres) en Bueres, Alberto y Kemelmajer de Carlucci, Aída (directores): Responsabilidad por daños en el tercer milenio: bomenaje al profesor doctor Atilio Aníbal Alterini (Buenos Aires, Abeledo - Perrot, 1997) pp. 121-126. 
- Fueyo Laneri, Fernando: Cumplimiento e incumplimiento de las obligaciones. Edición actualizada por el profesor Gonzalo FIGUEROA YÁÑEZ (Santiago, Editorial Jurídica de Chile, 2004, $3^{\text {a }}$ edición).

- GonzÁlez Guerrico, César: "Responsabilidad por los animales" en LÓPEZ CABANO, Roberto M. (coordinador): Responsabilidad civil objetiva (Buenos Aires, Abeledo - Perrot, 1995).

- Gumucio Rivas, Juan Esteban: "Ruptura del concepto clásico de responsabilidad civil en materia de accidentes del trabajo. Evolución de la legislación chilena" en Revista Laboral Chilena, volumen $8 \mathrm{n}^{\circ}$ 12, Dic. 1998, pp. 75-82.

- GuZmán Brito, Alejandro: II Derecho privado romano (Santiago, Editorial Jurídica de Chile, 1996).

- Larroumet, Christian: Responsabilidad civil contractual. Algunos temas modernos (Santiago, Editorial Jurídica de Chile, 1998, $1^{\text {a }}$ edición).

- LÓPEZ SANTA MARÍA, Jorge: "La responsabilidad patrimonial por falta de servicio. Casuística chilena reciente" en Responsabilidad por daños en el tercer milenio: bomenaje al profesor doctor Atilio Aníbal Alterini (Buenos Aires, Abeledo - Perrot, 1997) pp. 481-491.

: "La responsabilidad civil por productos" en AA.VV.: Derecho de daños (Santiago, LexisNexis, 2002) pp. 149-170.

- MARTínez Estay, José Ignacio: "La responsabilidad patrimonial del Estado por infracción al principio de igualdad y al derecho de propiedad en el derecho público chileno" en AA.VV.: Derecho de daños (Santiago, LexisNexis, 2002), pp. 171-201.

- Mazeud H. y otros: Tratado teórico y práctico de la responsabilidad civil delictual y contractual (Buenos Aires, Ediciones Jurídicas Europa América, 1961, $5^{a}$ edición).

- Molinari VAlDÉs, Aldo: De la responsabilidad civil al derecho de daños y tutela preventiva civil (Santiago, LexisNexis, 2004, $1^{\mathrm{a}}$ edición).

- Navarrete Barrueto, Jaime: "El origen de la responsabilidad civil objetiva en el derecho aéreo" en Revista Chilena de Derecbo, volumen $5 \mathrm{n}^{\circ}$ s 1-6, febrero-diciembre 1978, p. 160-177.

- Pierry Arrau, Pedro: “¿Es objetiva la responsabilidad del Estado? Estado actual de la jurisprudencia" en Revista de Derecho del Consejo de Defensa del Estado ${ }^{\circ} 11$ junio 2004 (Santiago, Consejo de Defensa del Estado, 2004) pp. 11-21.

- Planiol, Marcel: Traité pratique de droit civil français (1945). Edición traducida al español, VI Tratado práctico de Derecho Civil francés. Las Obligaciones: primera parte (Mario Díaz Cruz, Habana, Editorial Cultural S.A., 1946).

- Rodríguez Grez, Pablo: La abligación como deber de conducta típica (La teoría de la imprevisión en Chile) (Santiago, Facultad de Derecho de la Universidad de Chile, 1992, $1^{a}$ edición). 
: Responsabilidad extracontractual (Santiago, Editorial Jurídica de Chile, 2002, $1^{\text {a }}$ edición).

- Soto KLoss, Eduardo: II Derecho Administrativo. Bases fundamentales. El principio de juridicidad (Santiago, Editorial Jurídica de Chile, 1996, $1^{\text {a }}$ edición).

- Süss, TH.: "La evolución de la responsabilidad por riesgo en el moderno derecho alemán" en Revista de Derecho Privado volumen XXVII $\mathrm{n}^{\circ} 311$ año 1943 , pp. 54-73.

- Tomasello Hart, Leslie: Estudios de Derecho Privado (Valparaíso, EDEVAL, 1994).

- VÁzQuez Ferreyra, Roberto: Responsabilidad por daños (elementos) (Buenos Aires, Ediciones Desalma, 1993).

- Yuseff Quirós, Gonzalo: Fundamentos de la responsabilidad civil y la responsabilidad objetiva (Santiago. Editorial La Ley, 2000, 1ª edición).

- Zelaya Etchegaray, Pedro: "El cúmulo u opción de responsabilidades en la nueva ley de protección al consumidor" en CORRAL TALCIANI, Hernán (editor): Derecho del consumo y protección al consumidor (Santiago, Cuadernos de Extensión, Universidad de los Andes, 1999), pp. 213-250.

: "La responsabilidad subsidiaria del dueño de obra por los accidentes y daños experimentados por el trabajador del contratista" en Baraona GonZÁlez, Jorge y Zelaya EtChegaray, Pedro (editores): La responsabilidad por accidentes del trabajo (Santiago, Cuadernos de Extensión Jurídica 10, Facultad de Derecho Universidad de los Andes, 2005) pp. 99-122. 